\title{
Pricing of Eco-labels with Retailer Heterogeneity
}

Frank Asche(a)*, Thomas A. Larsen(b), Martin D. Smith (c), Geir Sogn-Grundvåg(b), James A. Young(d)

(a) Department of Industrial Economics, Risk Management and Planning, University of Stavanger, Ullandhaug, 4036 Stavanger, Norway. Tlf. (47) 51832286, Fax. (47) 51831750. (b) Norwegian Institute of Food, Fisheries and Aquaculture Research, Muninbakken 9-13, PBox 6122, 9192 Tromsø, Norway.

(c) Nicholas School of the Environment, Duke University, Durham, NC 27701, USA.

(d) Marketing and Retail Division, Stirling Management School, University of Stirling, Scotland FK9 4LA.

E-mail addresses: frank.asche@uis.no (F Asche), geir.sogn-grundvag@nofima.no (G SognGrundvåg), thomas.andre.larsen@nofima.no (T A Larsen), marsmith@duke.edu (M D Smith), j.a.young@stir.ac.uk (J A Young)

* corresponding author

October 25, 2014

\begin{abstract}
Eco-labels are important features of many natural resource and food markets. They certify that a product has some desirable unobserved quality, typically related to a public good such as being sustainably produced. Two issues that have received limited attention are whether pricing varies across different eco-labels that may compete with each other and to what extent different retailers charge different prices. Using a unique data set of salmon prices in eight different United Kingdom retail chains, we investigate these issues by estimating a price-attribute model that includes two eco-labels and one country-of-origin label. Results show substantial variation in the prices of the different eco-labels and that eco-label premiums vary across retail chains. Specifically, salmon certified with the Marine Stewardship Council (MSC) label has a high premium in low-end retail chains but no statistically significant premium in the high-end chains. These findings question the ability of the MSC label to transmit consumer willingness-to-pay for public goods through the supply chain to incentivize sustainable management. In contrast, premiums for organic certification are similar in magnitude across retailer types. In general, failure to account for retailer heterogeneity will over- or under-estimate a label's premium.
\end{abstract}

The authors thank Lori S. Bennear for helpful discussions, Duncan J. Young for meticulous data collection and the Norwegian Fishery and Aquaculture Industry Research Fund and the Norwegian Ministry of Fisheries and Coastal Affairs for financial support. 


\title{
Pricing of Eco-labels with Retailer Heterogeneity
}

\begin{abstract}
Eco-labels are important features of many natural resource and food markets. They certify that a product has some desirable unobserved quality, typically related to a public good such as being sustainably produced. Two issues that have received limited attention are whether pricing varies across different eco-labels that may compete with each other and to what extent different retailers charge different prices. Using a unique data set of salmon prices in eight different United Kingdom retail chains, we investigate these issues by estimating a price-attribute model that includes two eco-labels and one country-of-origin label. Results show substantial variation in the prices of the different eco-labels and that eco-label premiums vary across retail chains. Specifically, salmon certified with the Marine Stewardship Council (MSC) label has a high premium in low-end retail chains but no statistically significant premium in the high-end chains. These findings question the ability of the MSC label to transmit consumer willingness-to-pay for public goods through the supply chain to incentivize sustainable management. In contrast, premiums for organic certification are similar in magnitude across retailer types. In general, failure to account for retailer heterogeneity will over- or under-estimate a label's premium.
\end{abstract}

\section{Introduction}

Product labels are important in many natural resource and food markets. Like other certification schemes, labels attempt to solve asymmetric information problems by signaling that the product or its production process has some intrinsic quality that is otherwise difficult for the consumer to observe. Some labels are affixed to impure public goods that provide both private benefits—e.g. taste, freshness and health—and public benefits that an individual consumer cannot fully appropriate-e.g. environmental sustainability and fair employment practices. We refer to these labels as eco-labels, recognizing that some of the public goods dimensions are social rather than environmental objectives.

A successful eco-label would be one that transmits consumer demand for a public good through the supply chain and, in so doing, creates incentives for sustainable practices 
or management. As a starting point, a label must be able communicate the sustainable practices of the firm and the associated private or public benefits. The label must then be able to verify credentials of certified firms. To transmit incentives, the links in this chain would be: 1) existence of consumer willingness-to-pay, 2) a positive price premium at the retail level (i.e. a higher retail price), 3) transmission of the retail premium from retailer to wholesaler, 4) transmission of the premium from wholesaler to producer, and 5) resulting changes in producer behavior toward more sustainable practices and/or producer support for sustainable management. Stated preference studies consistently find evidence for the first link in this chain. Consumers are willing to pay for a wide range of eco-labels that signal sustainably harvested fish and forestry products (Wessells et al. 1999; Johnston et al, 2001; Aguilar and Vlosky, 2007), organically grown food (Bond, Thilmany, and Keeling Bond 2008; Lusk and Briggeman 2009), fair trade (De Pelsmacker, Driesen, and Rayp 2005;), and contains no genetically modified (GM) materials (Loureiro and Hine 2002; Lusk et al. 2005). However, existence of willingness-to-pay for an eco-label is not a sufficient condition for a market premium (Sedjo and Swallow 2002). There are open questions about whether retailers can capture willingness-to-pay and pass it along through the supply chain to the actors who ultimately affect sustainability. ${ }^{1}$

Although willingness-to-pay for eco-labels is well established in constructed

${ }^{1}$ Another motivation for eco-labels is market access, namely being able to sell products to certain countries, wholesalers, and retailers. On the surface, market access appears distinct from price premium, but it amounts to a similar incentive. A producer who is denied market access is unable to sell to the preferred market and instead must sell to the less preferred market. The preferred market is preferred by the seller because it is more profitable to sell in that market. The preferred market thus offers a higher price or a lower cost of doing business. Although we do not have data to explore the cost dimension, we have no reason to expect that doing business with different retail chains systematically varies by whether they are high-end or low-end retailers. 
markets, real consumers simultaneously choose where to shop, a bundle of other goods in conjunction with a labeled product, and a labeled or unlabeled product from a choice set with heterogeneous labels. This reality creates problems for measuring the second link in the chain that connects eco-labels to sustainability; real-world pricing of eco-labels may be influenced by retailer profiles and competition across labels. For instance, it may be that retailers choose premiums to attract people to the stores, and the eco-label premiums may to some extent reflect this phenomenon. While some studies find retail price premiums for eco-labeled products (Roheim, Asche and Insignares 2012; Sogn-Grundvåg, Larsen and Young 2013; 2014), they do not account for potential supply chain diversity and implicitly assume that all retailers are identical. Two key aspects of this diversity are thus: 1) price premiums when consumers can choose among products with different eco-labels and 2) the potential for overall retailer profiles to obscure a label's price premium. ${ }^{2}$

Here we investigate whether actual retail prices vary across different eco-labels for salmon, and whether the eco-label premium varies by retailer. To quantify retailer price premiums, we use a unique data set of 6,618 weekly price observations of a wide range of salmon products sold in eight UK retail chains. These prices are net of any in-store specials or discounts. In contrast to scanner data, which typically contain information on a limited number of product attributes that do not include eco-labels, our data allow us to access all product attributes, including two eco-labels, organic and Marine Stewardship Council (MSC)

\footnotetext{
${ }^{2}$ In the stated preference literature, Onazaka and Thilmany McFadden (2011), investigate willingness-to-pay for, respectively, organic, fair trade, carbon footprint and production location and find different preferences for the different eco-labels. Moreover, while some combinations of eco-labels may enhance willingness-to-pay, others lead to a discount.
} 
certified. ${ }^{3}$ Though not an eco-label, we also control for country-of-origin (Scottish in our case) because there is evidence that consumers prefer domestic to imported products (Alfnes and Rickertsen, 2003; Lusk and Anderson, 2004). Not all stores carry every combination of product attributes. We assume throughout the analysis that all products compete in the same market; consumers are free to choose among the various products and retail outlets. Our results show substantial heterogeneity in eco-label premiums across retailers and across label type. We assume that products that are the same in every way except whether they contain the label have no product line cost differences, so differences in retail prices, controlling for all other attributes, are meaningful. These results raise new questions about the extent to which eco-labels can successfully transmit consumer willness-to-pay for sustainability through the supply chain.

\section{Background}

The Food and Agriculture Organization of the United Nations (FAO) characterizes more than $50 \%$ of the world's fisheries as fully utilized and another $32 \%$ as overfished or recovering (FAO 2011). The prevalence of overfishing and the globalization of the seafood trade raise concerns not only about whether fish stocks are currently poorly managed but also whether some seafood exporting countries have the institutional capacity to govern their resources effectively in the future (Smith et al. 2010). Certification programs for sustainably managed resources and eco-labeling potentially allow consumers a voice and thereby provide incentives for better resource governance (Wessells et al, 1999).

\footnotetext{
${ }^{3}$ Roheim, Asche and Insignaris (2011) had to augment their scanner data with store observations to determine which products carried the MSC label.
} 
The most prominent eco-label in fisheries, at least in terms of the number of fisheries certified, is the MSC. The MSC label certifies fisheries according to three principles: sustainable fish stocks (i.e. avoiding overfishing), minimizing environmental impact (e.g. limit destructive fishing gear and bycatch), and effective management. Since the first capture fishery was certified as sustainable against the MSC's standards in 2000, the number of certified fisheries has grown to 189 as of January 2012 (MSC, 2013). Bioeconomic theory shows that a retail premium for eco-labeled fish is necessary to create incentives for sustainable management, but a premium is not a sufficient condition (Gudmundsson and Wessels 2000). While recent studies find a retail price premium for the MSC label (Roheim, Asche and Insignaris, 2011; Sogn-Grundvåg, Larsen and Young, 2013; 2014), the label is not without its controversies. Given that certification is costly, a natural concern is that the MSC premium is insufficient to cover the cost. A more serious concern is that fisheries management is not necessarily improved in fisheries certified by the MSC label (Jaquet et al, 2010). MSC-certified products appear to be sustainably managed (Gutièrrez et al, 2012), but this correlation does not establish that the process of becoming certified actually caused the sustainable outcomes. Despite these broader concerns, here we focus on quantifying the retail price premium as a step toward understanding the role of seafood eco-labels in promoting sustainability.

A unique feature of the MSC label is that it applies to products from an entire fishery for a common-pool resource, not simply to products from a subset of the firms in an industry. That means that individual firms are not certified. Rather, it is the collective behavior of fishing firms in conjunction with fisheries managers that determine whether a fishery can be certified. This all-or-nothing approach to solving a commons problem and 
providing public goods at the same time (e.g. restricting the use of destructive fishing gear) raises questions about whose behavior the label purports to change and how the premium is transmitted to these agents. ${ }^{4}$ Different fishing vessels often receive different prices for the fish that they land even in the absence of certification (McConnell and Strand 2000; Lee, 2014; Asche, Chen, and Smith 2015). Given the individual basis of fish prices and the collective nature of certification, it is unclear how a premium can be transmitted to individual vessels, how they would perceive the premium, and how it maintains incentives at the individual vessel (firm) level. Skepticism about MSC was underscored in January 2012 as the leading Alaskan salmon processors and thereby the Alaska Seafood Marketing Institute withdrew from certification after the 2012 season (Intrafish, 2012; Alaska Seafood Marketing Institute, 2012).

Another controversy in the literature is whether eco-labels, including MSC, act as trade barriers and deny market access (Salzman 2007). As discussed above (footnote 1), market access is equivalent to a price premium to the extent that sellers can earn more by accessing preferred markets. In developing countries, seafood eco-labeling raises questions about distributional consequences; when industrial countries insist on product labels, they may inadvertently privilege large producers over small ones, which may be unfair to small producers. In essence, because labeling requires often substantial investments by producers, requirements may disadvantage small operations relative to large ones that have more capacity to manage their supply chains (Tran et al. 2013). In essence, it may be unfair if only large producers can qualify for a premium by accessing preferred markets.

\footnotetext{
${ }^{4}$ What constitutes a "fishery" can be a matter of discussion and further complicate the MSC label.
} 
Until very recently, there has been no direct sustainability certification for seafood from aquaculture. ${ }^{5}$ To provide a signal of environmental quality similar to MSC, some farmed seafood is marketed and labeled as organic. Despite similarities, organic farmed seafood differs from wild-caught MSC-labeled seafood in that the environmental problems are different (the commons problem, destructive gear and bycatch for MSC compared to nutrient pollution, antibiotic use and feed sources for aquaculture), and consumers may perceive private health benefits of consuming organic compared to conventional. Although there are studies of demand for organic salmon (Aarset and Young, 2004; Aarset et al, 2004;), none mirror the detailed price and other product observations incorporated here. Nevertheless, one would expect an organic premium, as some attributes are more costly to provide for an organic product, e.g. salmon coloring (Alfnes et al, 2006; Forsberg and Guttormsen, 2006).

Country-of-origin labeling tends to focus on consumer demand for private attributes such as food safety rather than public environmental goods (Loureiro and Umberger 2007). For seafood, generic marketing organizations like the Alaska Seafood Marketing Institute and the Norwegian Seafood Council have invested substantially in country-of-origin labeling and marketing of salmon. Kinnucan and Myrland (2002) provide evidence that these efforts are successful in producing premiums. Thus, isolating a premium for ecolabeled seafood must at least control for the potentially confounding effect of country-oforigin labeling. In our particular case, there are examples of country-of-origin labels coinciding with the organic label and others with a country-of-origin label not labeled

\footnotetext{
5 In 2010 the Aquaculture Stewardship Council (ASC) was established and provided a farmed parallel to the wild capture focus of the MSC with tilapia being the first ASC-certified species launched on the market in 2012 (http://www.asc-aqua.org). The Global Aquaculture Alliances backs a Best Aquaculture Practice that has been awarded for two years, but no studies exist with respect to its effect.
} 
organic. There are also examples of wild salmon with and without MSC labels, but wild salmon cannot be labeled organic.

Seven different types of salmonides are marketed; pink, chum, sockeye and chinook are primarily wild and Atlantic, coho and trout are primarily farmed. ${ }^{6}$ There have always been different premiums associated with the different species. The wild species pink and chum are often known as low-value salmon, while chinook, sockeye and wild coho are high value salmon. Traditionally, Atlantic salmon has also been regarded as high-value salmon. Asche, Bremnes and Wessells (1999) and Asche et al (2005) quantify the price hierarchy and show that it is stable. It is also noteworthy that farmed was a positive attribute when the salmon farming industry was emerging (Holland and Wessells, 1998), but it later became a negative attribute (Roheim, Sudhukaran and Durham, 2012). Overall, this literature highlights the critical importance of controlling for salmon species and whether it is farmed or wild-caught in isolating eco-label premiums.

\section{Data}

The data for this study were collected by personal observation of a wide range of fresh, chilled and frozen farmed and wild salmon products in eight outlets representing eight different retail chains located in Glasgow, Scotland, UK.7 The eight retail chains are Asda, Coop, Lidl, Marks \& Spencer, Morrisons, Sainsbury's, Tesco and Waitrose. While there is some variation in the size of the stores sampled, the sample represents primarily medium

\footnotetext{
${ }^{6}$ The trout is primarily large rainbow trout and also known as salmon trout (Asche et al, 2005) or steelhead (Olson and Criddle, 2008). Wild coho is also available but in substantially less quantities than farmed. Wild Atlantic may also be found but in even smaller volumes and seldom, if ever, in large retail stores.

${ }^{7}$ Every product was purchased initially, and the packaging was retained. On subsequent visits, prices were recorded and packaging was spot checked for consistency with packaging from earlier time periods.
} 
and large stores but not the smallest. Although the smallest convenience outlets show the greatest price variability, no systematic deviations from each chain's standard prices were found. Collectively these retail chains accounted for $85.3 \%$ of the UK retail fish market by value in 2012 (Nielsen Scantrack, 2013). Although data collection through personal observation necessarily restricts the number of outlets that can be visited, we argue that this limitation is not a major concern because chains appear to coordinate their pricing strategies for all outlets in a region (Pesendorfer 2002). In our case, the assumption of a chain-level standard pricing policy is consistent with anecdotal observations of prices at other stores. Hence, we assume that the data set provides an unbiased picture of the pricing of the products in these UK chains. The data collection method has the advantage that all visible product attributes can be observed and analysed, including attributes that are not reported in other types of data or that are generally too expensive to acquire for all but commercial purposes. Roheim, Asche and Insignaris (2011), for example, could not obtain information on eco-labels from their scanner data and did not have access to the different individually named store brands. Moreover, we are able to study products that are not barcoded and that are sold as fresh.

The observations were conducted in Glasgow, the fourth largest city in the UK, and were done during the second half of the week when the product range and sales volumes normally are at their highest. The continuous weekly observations started November $14^{\text {th }}$, 2012 and the latest observation included was August $20^{\text {th }}, 2013$, a period of 41 weeks. A total of 223 salmon products were included in the study. Information regarding the physical product included method of production as in wild catch or farmed, product form (frozen, chilled etc), the mode of processing, brand, eco-label, weight, and price per kilo. Due to 
product line deletions and additions during the observation period, the data set is not a balanced panel, resulting in a total of 6,511 observations. Descriptive statistics are in Table 1. Details on products across supermarkets are in Appendix A (Table A1) along with sample images of labels (Figures A1-A2). None of the eco-labels are carried by all retail chains. The MSC-label is not carried by Coop and Sainsbury, ${ }^{8}$ only three chains carry salmon labeled as organic (Asda, Marks \& Spencer and Waitrose), and all chains but Lidl carry salmon labeled as Scottish.

Broader market data provide important context for our study. The domestic UK production all takes place in Scotland. Nearly half of the overall retail salmon market in the UK is imported salmon. $80 \%$ of UK salmon imports are farmed salmon from Norway. Besides Scotland and Norway, other major producers of farmed salmon are Chile, Ireland, Canada, and Faroe Islands. Major producers of wild salmon include the United States, Russia, Japan, and Canada (Asche and Bjørndal 2011).

\section{Model specification}

Our methodological approach follows Lancaster (1966) and decomposes the product price by its attributes. This approach has been used to quantify the value of various seafood product attributes at the landing point (McConnell and Strand, 2000), the wholesale level (Asche and Guillen, 2012) and the retail level (Roheim, Asche and Insignaris, 2011; SognGrundvåg, Larsen and Young, 2013). These studies typically estimate a single parameter for each product attribute. To capture potential differences in pricing strategies across retailers for the different eco-labels, we introduce a set of interaction variables. Our identification

\footnotetext{
8 That there are no MSC-labeled salmon products at Sainsbury is surprising, as they carry MSC-labeled products for other species (Sogn-Grundvåg, Larsen and Young, 2013).
} 
strategy is based on variation in product attribute combinations in the entire sample, not through matching products that are identical in every dimension except one.

We use a log-linear functional form, meaning that parameter estimates are interpreted as percentage deviations from a base product. In this way, the magnitudes of all coefficients in the regression models are scaled the same, additive, and directly comparable. The basic specification (Model 1) is:

$$
\ln P_{i t}=a+\sum_{j=2}^{J} b_{j} s_{j}+\sum_{k=2}^{K} c_{k} s_{k}+\sum_{l=2}^{L} d_{l} s_{l}+e_{i t},
$$

where $P_{i t}$ is the price of product $i$ at time $t$, and $s_{1}, \ldots, s_{n}$ is a vector of attributes that determine the price of the product. We employ dummy variable coding on the parameters $b_{j}, c_{k}, d_{l}$ for respectively the product attributes, the retailer attributes and the eco-label attributes listed in Table 1 . In all models, the base product is a farmed, chilled salmon fillet sold at Asda (an inexpensive retail chain). The base product also is un-processed, has no eco-label (neither MSC nor organic), carries the supermarket's own private label, has a package size between 100 and 250 grams, is not labeled "Scottish", and does not come with any sauce, dressing or other value added ingredients that might significantly reduce the product's fish content. While we do observe the private labels for each of the retailers, we cannot separate them from the retailer dummy. Hence, with respect to brands we explicitly specify the two leading brands, Birdseye and Young's Bluecrest, and have two additional groups: other brands and store brands. The base product attributes are excluded categories in the regressions.

Beyond the basic model, we introduce interaction dummies between the eco-labels and the retailers. The model becomes:

$$
\ln P_{i t}=a+\sum_{j=2}^{J} b_{j} s_{j}+\sum_{k=2}^{K} c_{k} s_{k}+\sum_{k=1}^{K} \sum_{l=1}^{L} f_{k l} s_{k l}+e_{i t},
$$


where $f_{k l}$ provides the interaction effect, showing how an eco-label is enhanced (positive value) or discounted (negative value) relative to the base case for any retailer. We estimate four versions of equation (2) (Models 2-5). Model 2 has all of the interaction variables, while models 3-5 have interaction variables for respectively one of the eco-labels or Scottish origin and the results are reported in Appendix A (Tables A4-A6). The econometric analysis was conducted using STATA with robust standard errors.

A feature that has not received attention in the earlier literature on the value of ecolabels is that the standard errors are not likely to be independent across units, but rather independent across some clusters of units and correlated within those clusters. Pricing of supermarkets in general limit price variation due to menu costs, and increasingly such features are present also for seafood (Kvaløy and Tveteras, 2008; Larsen and Asche, 2011). The potential for correlation among product types, preservation forms, or retailers could bias the estimated standard errors as in the clustered standard errors literature (Moutlon, 1990). Because there is no obvious criterion to select the unit of clustering, we estimate the models with different clustering units to evaluate the impact: by species, method of processing/preservation, retailer, product form, and a four dimensional cluster containing species, product form, and type of processing/preservation in the paper. Standard errors for clusters by other variable are reported in Appendix A (Tables A2-A3). The reported cluster dimensions are the dimensions where the estimated standard errors are most influenced (retailers with 8 clusters, products with 233 clusters and the four dimensional one with 57 clusters).

\section{Empirical Results}


We first investigate to what extent there is seasonality in prices by estimating the models with sets of weekly and 4-weekly dummy variables. ${ }^{9}$ Although the models with the seasonal dummies use additional degrees of freedom, the qualitative results are consistent with those in Models 1-5. The joint hypothesis that seasonal dummies are zero (without clustered errors) cannot be rejected in any of the cases (Table 2). ${ }^{10}$ The $F$-tests are consistent with not including the weekly or 4-weekly dummies in our preferred specifications; price deviations appear to be idiosyncratic and not due to a systematic seasonal or trend component. This finding is not surprising given that all products are packaged and most products are processed, exposing systematic price changes to menu costs. Price fluctuations of individual products within a store could reflect inventory management or loss leader pricing strategies.

Model 1 contains baseline labeling premium estimates with no interaction dummies along with unclustered robust standard errors and three different clusterings (Table 3). The model has high explanatory power $\left(\mathrm{R}^{2}=0.808\right)$. Most parameters are significant at a $5 \%$ level without clustering.

For all the eco-labels, there is a statistically significant premium in the specification with robust standard errors. The MSC premium is $13.1 \%$, which is very close to the $14.2 \%$ reported for Alaska Pollock by Roheim, Asche and Insignaris (2011) and the 10\% and 12\% reported for respectively haddock and whitefish by Sogn-Grundvåg, Larsen and Young $(2013 ; 2014)$. The premium is higher for organic at $25.3 \%$. Scottish origin has a $4 \%$ premium. With all the reported clusters, the MSC attribute becomes insignificant, as does

\footnotetext{
${ }^{9}$ Although we have data for only one year, these dummies could potentially capture a within year trend as well as seasonality.

${ }^{10}$ As the clustered standard errors are more conservative, the results are similar.
} 
the Scottish origin in two of the cluster dimensions. This result suggests that there is substantial correlation in these dimensions that must be accounted for when evaluating the impact of the eco-labels. In all specifications, an F-test for the hypothesis that the premium is equal for the three labels can be rejected with $p$-values less than 0.001 . Hence, there is strong evidence that the premium varies by label.

Results from retailer dummies are consistent with our prior expectations of retailer price hierarchies. There is a significant negative premium associated with Lidl, a discount chain, no premium associated with Morrisons, and all of the other chains command a higher price level than Asda. As expected, the high-end retail chains Marks \& Spencer and Waitrose have the highest general price levels. The results for other variables all conform to expectations: a negative premium for the low-value wild species chum and pink; a positive (though not robust) premium for sockeye, supporting the notion that there is a preference for wild salmon; positive premiums for smaller package sizes, slices, and value added ingredients but discounts for trimmings.

Overall, when the errors are clustered, most attributes remain statistically significant. In Appendix A, we report results from other clustering dimensions, which are somewhere between what are reported with the unclustered errors and the three cluster dimensions in Table 3. Retailer clustering captures a large part of the correlation, but that there is also some correlation in other dimensions that the other cluster dimensions are necessary to capture.

We next compute partial effects $\left(\eta^{2}\right)$ and sum them by variable group to understand more about the sources of variation in our data (Figure 1). Which retailer is selling the product is clearly the most important factor, contributing $41 \%$ to the total variation 
explained. Although we cannot decompose it further, the retailer effect presumably includes broad pricing strategy and selection of the product mix for stores. Product form and package size is also relatively important with respectively a contribution of $20 \%$ and 23\%. Eco-labels contribute relatively limited explanatory power, contributing just 3\%, which still is somewhat more than brands at $2 \%$.

Model 2 includes interaction dummies for the three types of labeling and has similar results for non-label attributes (Table 4). Note that the base categories for the interactions are no label, that is no MSC, no organic and no Scottish label. The interaction terms indicate that eco-labels have a significant premium for some retailers, and there is substantial variation in pricing strategies across different retail chains for the various labels (Figure 2). The variation is largest for the MSC label; the estimated premium varies from negative but statistically insignificant to $56.6 \%$ for Asda. The variation is almost as large for Scottish salmon, although this variation is primarily due to Tesco, which charges a 44\% premium. For most retailers, there is a moderate or no premium for Scottish origin on salmon, and for Morrison it is negative. The three retail chains that carry organic salmon charge relatively similar premiums at around 25\%. All organic premiums are statistically significant across error specifications, while all but one premium for Scottish origin is not robust to clustering.

For MSC, whether the standard errors are treated as clustered or not makes a substantial difference with respect to statistical significance. With robust errors, for two of the chains the MSC premium is not significantly different from zero, and the premiums charged by the discount chains Lidl and Asda are $27.6 \%$ and $57.0 \%$ respectively. With the errors clustered in the product dimension or multi-dimensional, only two MSC premiums 
remain statistically significant (Asda and Lidl). When the clustering is only in the retailer dimension, there is a significant premium associated also with Waitrose. ${ }^{11}$

Table 5 reports $F$-tests on the interactions of the label dummies with retailer dummies for Model 2 with standard errors clustered by product form. With one exception, the results are the same independently of which standard errors are used. The jointly column reports tests for the null that all these interaction dummies are jointly zero. The equality column reports tests for the null in which the interaction parameters are equal; that is, the null hypothesis is that the model can be reduced to Model 1. All of these restrictions are rejected with the exception of the null that the organic premiums are equal. This null hypothesis is rejected if the ordinary robust errors are used. Hence, with an exception for organic, the different retailers pursue different pricing strategies across ecolabeled and country-of-origin labeled salmon. Some charge a substantial premium while others do not charge any premium at all. This result is independent of whether one accounts for within group correlation by allowing the standard errors to be clustered or not. However, the premiums are statistically significant for more retailers when the standard errors are estimated less conservatively.

To clarify interpretation of our results further, consider two comparisons of retailers with MSC certification: Asda to Waitrose and Waitrose to Lidl. Treating MSC*Waitrose as zero (because it is statistically insignificant when clustering standard errors) and using point estimates for other coefficients that are significant, MSC-certified products are somewhat similarly priced for both Waitrose and Asda. The MSC-certified salmon is only

${ }^{11}$ We report results of intermediate steps between Models 1 and 2 in the appendix (Models 3-5) that represent different combinations of interactions of the eco-labels and origin labels with retailers. The base eco-label and origin label coefficients in Models 3-5 are highly robust and quantitatively similar to those in Model 1. 
$[(0+0.57)-(0.466+0)]=10.4 \%$ more expensive in Asda than in Waitrose. However, MSCcertified salmon is $[(0.466+0)-(-0.479+0.276)]=66.9 \%$ more expensive in Waitrose than in Lidl. Of course, the non-MSC labeled salmon is $[(0.466)-(-0.479)=94.5 \%$ more expensive in Waitrose than in Lidl, and non-MSC labeled salmon is [0.466-0] $=46.6 \%$ more expensive in Waitrose than in Asda. Hence, there is a substantial premium associated with MSC in the discount chains, and they are still supplying this fish at a lower price than Waitrose. Overall, these examples illustrate that there are important differences in pricing across retailers for labeled and unlabeled products. ${ }^{12}$

Overall, the results add to our understanding of how eco-labels are valued at the retail level. Our finding that the MSC eco-label commands an average price premium of 13.1\% (from Model 1) corroborates the findings from two earlier studies that found very similar premiums for MSC-labeled Alaska pollock (Roheim, Asche and Insignaris, 2011) haddock (Sogn-Grundvåg, Larsen and Young, 2013) and whitefish (Sogn-Grundvåg, Larsen and Young, 2014) in the UK retail market. Together these three studies, which cover two different regions in the UK (Glasgow and London) and three different species (salmon, Alaska pollock and haddock), suggest that in the UK, the MSC label captures some willingness to pay for public goods associated with this label. However, our results also clearly demonstrate that the eight retailers included in the study have adopted very different pricing strategies for eco-labels, and accordingly, the term "market premium" does not seems to be appropriate. Moreover, there appears to be substantial correlation for several attributes and particularly in the retail chain dimension. When accounted for, this

12 For completeness, we also tested whether the premiums associated with the labels are equal in pairs of labels (MSC to organic, MSC to Scottish, and organic to Scottish) as well as equality of all premiums in both models 1 and 2 . In all cases, we reject the null hypothesis of equal premium(s) with a $p$-value less than 0.001 . 
changes several of the intermediate conclusions substantially. It does not materially change the main conclusions in the preferred and most general model, although there are significant eco-label premiums associated with fewer retailers.

\section{Concluding remarks}

Our results on retail pricing of eco-labels show a complex picture with important implications for both research and practice. For other researchers attempting to quantify premiums for eco-labeled products, our findings strongly suggest that the potential impact of eco-labels (and origin) can only be assessed accurately when accounting for the fact that individual retailers charge different prices for eco-labels. Studies based on scanner data that do not specify individual retail chains may overlook important insights regarding the nature and heterogeneity of the market for eco-labels. In studies that rely on data from a single retailer, the eco-label premium could be over- or underestimated depending on the pricing strategy such as whether the retailer uses the eco-labeled product as a loss leader. This question of external validity helps to account for differences in measured retail ecolabel premiums in the literature. Use of a single retailer also suggests the potential for customer selection bias in attempts to understand consumer responses to both environmental signalling and screening. Hallstein and Villas-Boas (2013), for instance, show that the use of wallet cards (a form of third-party screening that provide purchasing recommendations) significantly reduces seafood purchases of species with a yellow label, but does not affect purchases of species with red or green labels. Yet they focus exclusively on a single high-end retailer in the San Francisco Bay Area, raising questions about how much incentive could be passed along the supply chain. On the other end of the spectrum, 
studies that use data from multiple retailers but that fail to control for eco-label/retailer interactions suffer from omitted variable bias. Nevertheless, our approach and ability to address some of the issues of external validity in other studies relies on the assumption that all products in our data set compete in the same market.

The highly segmented nature of the market for eco-labels also suggests that individual retail chains use eco-labels as one means of differentiation, at least with respect to their seafood offerings. As raised above, one possibility is that eco-labeled products are loss leaders as part of a broader profit maximization strategy across the collection of products sold. After all, MSC-labeled products are only a small fraction of all products sold but may help to bring consumers into stores. Alternatively, retailers may be concerned about price differences that are too large if consumers are inclined to interpret the price difference as a signal of low quality for the unlabeled product. Selling eco-labeled products may also serve a broader communications objective in that emphasis on the sustainability of the seafood category helps to infer, if not necessarily reflect, similar emphasis in other foods and non-foods. In this respect seafood may be a particularly apposite medium because it encompasses a number of discrete and very different characteristics. Selling ecolabeled seafood may be a part of a larger corporate sustainability campaign. U.S. retailer Wal-Mart reported that $76 \%$ of its seafood sold was third-party certified and an additional $8 \%$ was pursuing certification as of January 31,2012 , and the chain set a goal that $100 \%$ of its seafood would be working toward sustainable certification by June $2012 .{ }^{13}$ Fast food chain McDonald's recently announced that $100 \%$ of the seafood sold in its 14,000 U.S.

\footnotetext{
${ }^{13}$ http://corporate.walmart.com/global-responsibility/environmentsustainability/sustainable-seafood (Accessed February 11, 2013)
} 
restaurants would be MSC-certified. ${ }^{14}$ Some argue that large brands are pursuing these corporate sustainability efforts to secure their supply chains for the long term (Dauvergne and Lister 2011). Undoubtedly, companies like Wal-Mart and McDonald's have a stake in securing large and steady flows of product that could be compromised by unsustainable practices. However, they also have a stake in projecting positive corporate image. Sustainable seafood may be a relatively inexpensive way to highlight green practices because seafood accounts for a small fraction of sales but is prominent in the media.

For labels that are intended to provide producers with incentives to produce sustainably, the different pricing strategies also raise important questions. For instance, one may wonder to what extent any premium is passed on to fishers and other earlier supply chain actors when the premium varies between zero and 57\%, and the premium is largest for the discount chains. If the MSC label indeed encourages better practices at sea, either the incentive comes from the subset of retailers that sell fish with an actual premium, or other retailers are absorbing the cost. ${ }^{15}$ If neither is true, it is hard to see that the label creates incentives.

The recent strategic business decision of the Alaskan salmon industry to drop MSCcertification can be understood in terms of basic economic incentives. In essence, the benefits of certification seem not to have outweighed the costs. It could literally be the case that the premium for MSC-certified salmon was absent, too small, or at best distorted and ill-received. Interestingly, the Alaskan salmon industry established certification through the

\footnotetext{
${ }^{14}$ http://www.huffingtonpost.com/2013/01/24/mcdonalds-fishsustainable n 2542502.html (Accessed Feburary 11, 2013)

15 Though we cannot observe it directly in our data, it may also be that retailers choose not to include the eco-label on some of the certified product that they purchase but thereby, if challenged, remain able to conform with any consumer concerns that they source sustainable products.
} 
Responsible Fisheries Management label subsequent to dropping MSC (IntraFish, "No MSC? No Problem; RFM Oks Alaska salmon again," 03.09.2013), which suggests that the industry finds it worthwhile to carry some eco-label. As such, one may argue that producers disagreed with MSC on the criteria for certification. But such disagreements effectively translate into the costs of meeting MSC standards being too high, and high costs, in turn, is just another version of the benefits of certification not being high enough. Politicians have also entered the discussion with Alaska Senator Lisa Murkowski introducing a bill that "would prohibit any federal agency from requiring or endorsing the use of any third party non-governmental organization's label, criteria or other scheme to certify fish or seafood as sustainable." (J. Fiorillo, IntraFish, "Lawmaker introduces bill to restrict use of MSC certification for US government agencies," 19.09.13) As the Alaska salmon experience continues to unfold, questions continue to emerge about future candidate fisheries for MSC and other eco-label certifications as well as retailers' interpretations of how their sustainable products might best be marketed.

Questions about how eco-label premiums are transmitted through the supply chain to the actors who ultimately affect sustainability (fishermen, fish farmers, and fishery managers) highlight a key limitation of the attribute-based approach to price premiums, namely lack of quantity data. Because we do not observe quantities sold, we do not know whether high- or low-premium pricing strategies move more eco-labeled product. Suppose that the high-end retailers sell most of the MSC-labeled salmon and that low-end retailers sell little. Because high-end retailers have the lowest premiums, then the average premium passed through to the harvest sector will be low. The opposite would be true if the low-end retailers sell most of the MSC-labeled salmon. The Alaskan salmon industry's decision 
would seem most consistent with the former. It could even be the case that retail pricing strategies deliberately discourage the purchase of eco-labeled products; simply including these products in stores and not necessarily selling them would then be part of projecting a positive corporate socially responsible image.

The role of eco-labels in private provision of public goods is still not well understood. When consumers can choose an impure public good that jointly produces a private good and an environmental public good, welfare can increase or decrease, depending on the responsiveness of consumers to the environmental attribute (Kotchen 2006). Understanding consumer demand for eco-labels thus is an important step in evaluating the overall potential for markets to provide public goods. Our analysis provides one important piece of this puzzle by illustrating the importance of retailer pricing strategies. The amount of premium, if any, that is transmitted back to agents that affect environmental outcomes and whether eco-labels cause behaviors to change are still open questions. Moreover, whether consumer expenditures on eco-labeled products crowd out direct contributions to public goods-a mechanism through which increased demand for a green product can theoretically lower environmental quality (Kotchen 2005) — and whether private provision can overcome free riding to be a viable alternative to public provision are all unknowns. Exploring these other links in the chain are important questions for future research. 


\section{References}

Aarset, B. and Young, J.A. (2004) Aquatic foods: options for organic growth? Aquatic Resources, Culture and Development 1(1):1-9.

Aarset, B., Beckmann, S., Bigne,J., Beveridge, M.C., Bjørndal, T., Bunting, M.J., McDonagh, P., Mariojouls, C., Muir, J.F., Prothero, A., Reisch, L.A., Smith, A., Tveteras, R. and Young, J.A. (2004) The European Consumers' Understanding and Perceptions of the 'Organic' Food Regime: The Case of Aquaculture. British Food Journal. 106(2): 93105.

Aguilar, F. X. and R.P. Vlosky (2007). "Consumer Willingness to Pay Price Premiums for Environmentally Certified Wood Products in the U.S," Forest Policy and Economics 9: 1100-12.

Alaska Seafood marketing Institute (2012) Alaska Salmon Processors Clarify MSC Salmon Position, 19.05.12, www.pressroom.alaskaseafood.org/alaska-salmon-processorsclarify-msc-position/

Alfnes, F., Guttormsen, A. G., Steine, G. \& Kolstad, K. (2006) Consumers' willingness to pay for the color of salmon: a choice experiment with real economic incentives. American Journal of Agricultural Economics, 88, 1050-1061.

Alfnes, F. And K. Rickertsen (2003) European Consumers' Willingness to Pay for US Beef in Experimental Auction Markets, American Journal of Agricultural Economics, 85, 396-405.

Asche, F. and T. Bjørndal (2011) The Economics of Salmon Aquaculture, Wiley-Blackwell: Chichester.

Asche, F., H. Bremnes and C. R. Wessells (1999) Product Aggregation, Market Integration and Relationships Between Prices: An Application to World Salmon Markets. American Journal of Agricultural Economics, 81, 568-581

Asche, F., Y. Chen and M. Smith (2015) Economic incentives to target species and fish size: Prices and fine scale product attributes in Norwegian fisheries. Forthcomming in ICES Journal of Marine Science.

Asche, F., Guttormsen, A. G., Sebulonsen, T. and Sissener, E. H. (2005) Competition between farmed and wild salmon: The Japanese salmon market. Agricultural Economics, 33, 333-340.

Asche, F. and J. Guillen (2012) The Importance of Fishing Method, Gear and Origin: The Spanish Hake Market, Marine Policy, 36, 365-369.

Bond, C. A., D. Thilmany, and J. Keeling Bond (2008) What to Choose? The Value of Label Claims to Fresh Produce Consumers. Journal of Agricultural and Resource Economics 33(3): 402-427.

Dauvergne, P., \& Lister, J. (2011). Big brand sustainability: Governance prospects and environmental limits. Global Environmental Change.

Davidson, R. and J.G. MacKinnon. (2004). Econometric Theory and Methods. Oxford University Press, New York.

De Pelsmacker, P., L. Driesen, and G. Rayp. 2005. Do Consumers Care about Ethics? Willingness to Pay for Fair-Trade Cof- fee. Journal of Consumer Affairs 39(2): 363-385.

Food and Agricultural Organization of the United Nations (FAO). (2011). The State of World Fisheries and Aquaculture 2010. Fisheries and Aquaculture Department, Rome.

Forsberg, O. I. and Guttormsen, A. G. (2006) Modeling optimal dietary pigmentation strategies in farmed Atlantic salmon: Application of mixed-integer non-linear mathematical programming techniques. Aquaculture, 261, 118-124.

Gutièrrez, N., S. R. Valencia, T. A. Branch, D. J. Agnew, J. K. Baum, P. L. Bianchi, J. Cornejo-Donoso, C. Costello, O. Defo, T. E. Essington, R. Hillborn, D. D. Hoggarth, A. E. Larsen, C. Ninnes, K. Sainsbury, R. L. Selden, S.Sistla, A. D. M. Smith, A. Stern-Pirlot, S. J. Tech, J. T. Thorson and N. E. Williams (2012) Eco-Label Convey Reliable Information on Fish Stock Health to Seafood Consumers, PloseOne 7(8): e43765. Doi:10.1371/journal.pone.0043765. 
Gudmundsson, E. and C. Roheim Wessells. 2001. "Ecolabeling Seafood for Sustainable Production: Implications for Fisheries Management," Marine Resource Economics, 15:97-113.

Hallstein, E. and S. B. Villas-Boas, 2013. "Are Consumers Color Blind? An Empirical Investigation of a Traffic Light Advisory for Sustainable Seafood." Journal of Environmental Economics and Management, 66: 52-71.

Holland, D. \& Wessells, C. R. (1998) Predicting Consumer Preferences for Fresh Salmon: The Influence of Safety Inspection and Production Method Attributes. Agricultural and Resource Economics Review, 27, 1-14.

Intrafish (2013) Five companies agree to continue using MSC eco-label for Alaska Salmon, 22.10.12.

Intrafish (2012) Alaska Salmon Processors Quit MSC, 18.01.12.

Jacquet, J., D. Pauly, D. Ainley, S. Holt, P. Dayton and J. Jackson (2010) Seafood Stewardship in Crisis, Nature, 467, 28-29.

Johnston, R.J., C. Roheim Wessells, H. Donath, and F. Asche. (2001) "Measuring Consumer Preferences for Ecolabeled Seafood: An International Comparison," Journal of Agricultural and Resource Economics, 26:20-39.

Kinnucan, H. W. and Myrland, Ø. (2002) The Relative Impact of the Norway-EU Salmon Agreement: A Mid-term Assessment. Journal of Agricultural Economics, 53, 195-220.

Kotchen, M. J. (2005). Impure public goods and the comparative statics of environmentally friendly consumption. Journal of environmental economics and management, 49(2), 281-300.

Kotchen, M.J. (2006) Green markets and private provision of public goods, Journal of Political Economy, $114,816-834$.

Kristofersson, D. and K. Rickertsen (2004) Efficient Estimation of Hedonic Inverse Input Demand Systems, American Journal of Agricultural Economics, 86, 1127-1137.

Lancaster, K.J. 1966. A New Approach to Consumer Theory. Journal of Political Economy 74:132-57.

Larsen, T. A. and F. Asche (2011) Contracts in the Salmon Aquaculture Industry: An analysis of Norwegian Salmon Exports. Marine Resource Economics, 26(2), 141-149.Lee, M. Y. 2014.

Hedonic Pricing of Atlantic Cod: Effects of Size, Freshness, and Gear. Marine Resource Economics, 29: 259-277.

Loureiro, M.L., and W.J. Umberger (2007) A choice experiment model for beef: What US consumer responses tell us about relative preferences for food safety, country-of-origin labeling and traceability. Food Policy 32.4: 496-514.

Lusk, J. L., and J. D. Anderson. 2004. Effects of Country-of-Origin Labeling on Meat Producers and Consumers. Journal of Agricultural and Resource Economics 29(2): $185-205$.

Lusk, J. L., and B. C. Briggeman. 2009. Food Values. American Journal of Agricultural Economics 91(1): 184-196.

Lusk, J. L., M. Jamal, L. Kurlander, M. Roucan, and L. Taulman. 2005. A Meta-analysis of Genetically Modified Food Valuation Studies. Journal of Agricultural and Resource Economics 30(1): 28-44.

Marine Stewardship Council (MSC). 2013. Annual Report 2008/09. http://www.msc.org/documents/mscbrochures/annual-report-archive/MSC-annual-report-2008-09.pdf/view. (last accessed March 25, 2010).

MacKinnon, J.G. and H. White. (1985). "Some heteroskedasticity consistent covariance matrix estimators with improved finite sample properties," Journal of Econometrics, 29: 305-25.

McConnell, K. and I. Strand. (2000). "Hedonic Prices for Fish: Tuna Prices in Hawaii," American Journal of Agricultural Economics. 82:133-44.

Moulton, B. R. (1990). An illustration of a pitfall in estimating the effects of aggregate variables on micro units. The Review of Economics and Statistics, 334-338. 
Nielsen Scantrack, (2013) 'Retail Market Data', (accessed March, 2013), [available at:

http://www.seafish.org/media/publications/temp_secure/default.asp?FolderSpec=\%2Fmedia $\% 2 \mathrm{Fp}$

ublications\%2Ftemp\%5Fsecure\%2FRetail+Market+Data\%2F2013+Neilsen+Retail+Data\%2F01

$\% 2 \mathrm{E}+$ Nielsen+Retail+Reports+to+5th+Jan+2013\&sort=2].

Olson, T. K. and K. Criddle (2008) Industrial Evolution: A Case Study of Chilean Salmon Aquaculture, Aquaculture Economics and Management, 12, 89-106.

Onozaka, Y. and D. Thilmany McFadden (2011) Does Local Labeling Complement or Compete with other Sustainable Labels? A Conjoint Analysis of Direct and Joint Values for Fresh Produce Claims. American Journal of Agricultural Economics, 93, 693-706.

Pesendorfer, M. (2002). Retail sales: A study of pricing behavior in supermarkets. The Journal of Business, 75(1), 33-66.

Roheim, C.A., F. Asche, and J. Insignares. 2011. The Elusive Price Premium for Ecolabelled Products: Evidence from Seafood in the UK Market. Journal of Agricultural Economics 62(3):655-668.

Roheim, C. A., Sudhakaran, P. O. and Durham, C. A. (2012) Certification of Shrimp and Salmon for Best Aquaculture Practices: Assessing consumer preferences in Rhode Island. Aquaculture Economics and Management, 16, 266-286.

Salzman, J. (2008). Informing the green consumer: The debate over the use and abuse of environmental labels. Journal of Industrial Ecology, 1(2), 11-21.

Sedjo, R. and S. Swallow. (2002) "Voluntary Eco-Labeling and the Price Premium," Land Economics, 78:272-84.

Smith, M. D., C. A. Roheim, L. B. Crowder, B. S. Halpern, M. Turnipseed, J. L. Anderson, F. Asche, L. Bourillón, A. G. Guttormsen, A. Kahn, L. A Liguori, A. McNevin, M. O'Connor, D. Squires, P. Tyedemers, C. Brownstein, K. Carden, D. H. Klinger, R. Sagarin, K. A. Selkoe (2010) Sustainability and Global Seafood, Science, 327, 784786.

Sogn-Grundvåg, G., T. Larsen, and J. A. Young (2013) The value of line-caught and other attributes: An exploration of price premiums for chilled fish in UK supermarkets, Marine Policy, 38 (March), 41-44.

Sogn-Grundvåg, G., T. Larsen, and J. A. Young (2014). Product Differentiation with Credence Attributes and Private Labels: The Case of Whitefish in UK Supermarkets. Journal of Agricultural Economics, 65 (2), 368-382.

Tran, N., C. Bailey, N. Wilson, and M. Phillips (2013), Governance of Global Value Chains in Response to Food Safety and Certification Standards: The Case of Shrimp from Vietnam. . Forthcoming, World Development

Wessells, C.R., R. Johnston, and H. Donath. (1999) "Assessing Consumer Preferences for Ecolabeled Seafood: The Influence of Species, Certifier, and Household Attributes," American Journal of Agricultural Economics, 81:1084-1089. 
Table 1

Descriptive statistics

\begin{tabular}{|c|c|c|c|}
\hline Variables & Description & Mean & StDev \\
\hline Price & Price per kg (£) & 21.959 & 11.046 \\
\hline Ln Price & Logarithm of price per $\mathrm{kg}$ & 2.970 & 0.494 \\
\hline Chum or Pink & 1 if chum/pink, 0 if otherwise & 0.087 & \\
\hline Sockeye & 1 if sockeye, 0 if otherwise & 0.018 & \\
\hline Other wild & 1 if other wild, 0 if otherwise & 0.021 & \\
\hline Farmed* & 1 if farmed, 0 if wild & 0.874 & \\
\hline Chilled* & 1 if chilled, 0 otherwise & 0.823 & \\
\hline Fresh & 1 if fresh, 0 otherwise & 0.066 & \\
\hline Frozen & 1 if frozen, 0 otherwise & 0.111 & \\
\hline Fillets* & 1 if fillets, 0 otherwise & 0.698 & \\
\hline Flakes & 1 if flakes, 0 otherwise & 0.028 & \\
\hline Slices & 1 if slices, 0 otherwise & 0.223 & \\
\hline Trimmings & 1 if trimmings, 0 otherwise & 0.028 & \\
\hline Other product form & 1 if whole, side or steak, 0 otherwise & 0.020 & \\
\hline Smoked & 1 if smoked, 0 if natural & 0.484 & \\
\hline Gravlox & 1 if graved, 0 otherwise & 0.014 & \\
\hline Added ingredients & 1 if added ingredients, 0 otherwise & 0.098 & \\
\hline Weight < 100 gr. & 1 if $<100$ gr., 0 otherwise & 0.018 & \\
\hline Weight $100-250$ gr.* & 1 if $100-250$ gr., 0 otherwise & 0.653 & \\
\hline Weight $250-500$ gr. & 1 if $250-500$ gr., 0 otherwise & 0.195 & \\
\hline Weight 500-900 gr. & 1 if 500-900 gr., 0 otherwise & 0.059 & \\
\hline Weight individual & 1 if individual weight, 0 otherwise & 0.078 & \\
\hline Bird's Eye & 1 if BEY, 0 otherwise & 0.026 & \\
\hline Young's & 1 if $Y N G, 0$ otherwise & 0.034 & \\
\hline Other brands & 1 if other brands, 0 otherwise & 0.101 & \\
\hline Private labels* & 1 if private labels, 0 otherwise & 0.779 & \\
\hline MSC & 1 if MSC, 0 otherwise & 0.059 & \\
\hline Organic & 1 if organic, 0 otherwise & 0.051 & \\
\hline Unlabeled* & 1 if unlabeled, 0 otherwise & 0.890 & \\
\hline Scottish & 1 if Scottish, 0 otherwise & 0.428 & \\
\hline ASDA* & 1 if Asda, 0 otherwise & 0.236 & \\
\hline COOP & 1 if Coop, 0 otherwise & 0.111 & \\
\hline LIDL & 1 if Lidl, 0 otherwise & 0.035 & \\
\hline Marks and Spencer & 1 if Marks, 0 otherwise & 0.178 & \\
\hline Morrisons & 1 if Mors, 0 otherwise & 0.124 & \\
\hline Sainsbury's & 1 if Sain, 0 otherwise & 0.069 & \\
\hline Tesco & 1 if Tesc, 0 otherwise & 0.069 & \\
\hline Waitrose & 1 if Wait, 0 otherwise & 0.177 & \\
\hline
\end{tabular}

* Base categories in regression 
Table 2. Seasonality tests

\begin{tabular}{ccccl}
\hline Model & \multicolumn{2}{c}{ Weekly } & \multicolumn{2}{c}{ 4-weekly } \\
& $F$-value & Prob $>$ & $F$-value & Prob $>$ \\
& & $\mathrm{F}$ & & $\mathrm{F}$ \\
\hline 1 & 0.54 & 0.993 & 1.43 & 0.167 \\
2 & 0.57 & 0.986 & 1.52 & 0.136 \\
3 & 0.54 & 0.993 & 1.42 & 0.171 \\
4 & 0.54 & 0.993 & 1.38 & 0.191 \\
5 & 0.57 & 0.986 & 1.48 & 0.148 \\
\hline
\end{tabular}


Table 3. Parameter estimates from model 1

\begin{tabular}{|c|c|c|c|c|c|}
\hline \multirow[t]{2}{*}{ Variable } & \multirow[t]{2}{*}{ Parameter } & \multicolumn{3}{|c|}{ St. Error } & \multirow[b]{2}{*}{ Multi } \\
\hline & & No cluster & Retailer & Product & \\
\hline \multicolumn{6}{|l|}{ Species } \\
\hline Chum or Pink & -0.195 & $0.020^{*}$ & $0.088 *$ & $0.094 *$ & $0.087^{*}$ \\
\hline Sockeye & 0.126 & $0.029 *$ & 0.099 & 0.133 & 0.124 \\
\hline Wild Alaska & -0.089 & $0.043^{*}$ & 0.142 & 0.163 & 0.136 \\
\hline \multicolumn{6}{|l|}{ Preserved } \\
\hline Fresh & -0.255 & $0.013^{*}$ & $0.080 *$ & $0.060 *$ & $0.066^{*}$ \\
\hline Frozen & -0.187 & $0.014 *$ & $0.080 *$ & $0.057^{*}$ & $0.055^{*}$ \\
\hline \multicolumn{6}{|l|}{ Product form } \\
\hline Flakes & 0.138 & $0.011^{*}$ & $0.056 *$ & $0.059 *$ & $0.057^{*}$ \\
\hline Slices & 0.252 & $0.009 *$ & $0.059 *$ & $0.050 *$ & $0.049 *$ \\
\hline Trims & -0.724 & $0.021 *$ & $0.118^{*}$ & $0.126^{*}$ & $0.132 *$ \\
\hline Other prod. & -0.183 & $0.035^{*}$ & 0.132 & 0.128 & 0.127 \\
\hline \multicolumn{6}{|l|}{ Processing } \\
\hline Smoked & 0.209 & $0.007^{*}$ & $0.024 *$ & $0.038 *$ & $0.033^{*}$ \\
\hline Gravlox & 0.023 & 0.020 & 0.067 & 0.081 & 0.070 \\
\hline Value added & 0.033 & $0.008^{*}$ & 0.045 & 0.037 & 0.041 \\
\hline \multicolumn{6}{|l|}{ Package size } \\
\hline Wgt_90 & 0.516 & $0.022^{*}$ & $0.075^{*}$ & $0.104 *$ & $0.113^{*}$ \\
\hline Wgt_250_500 & -0.291 & $0.007^{*}$ & $0.023^{*}$ & $0.036 *$ & $0.032 *$ \\
\hline Wgt_500 & -0.407 & $0.012^{*}$ & $0.026 *$ & $0.048 *$ & $0.042 *$ \\
\hline Wgt_ind & -0.339 & $0.013^{*}$ & $0.051^{*}$ & $0.054^{*}$ & $0.045^{*}$ \\
\hline \multicolumn{6}{|l|}{ Brand } \\
\hline Bird's Eye & 0.308 & $0.022^{*}$ & $0.113^{*}$ & $0.097^{*}$ & $0.087^{*}$ \\
\hline Young's & 0.018 & 0.017 & 0.039 & 0.091 & 0.080 \\
\hline Other brand & 0.126 & $0.011^{*}$ & $0.068 * *$ & $0.059 *$ & $0.059 *$ \\
\hline \multicolumn{6}{|l|}{ Eco-label } \\
\hline MSC & 0.131 & $0.025^{*}$ & 0.101 & 0.107 & 0.090 \\
\hline Organic & 0.253 & $0.008^{*}$ & $0.026^{*}$ & $0.046^{*}$ & $0.035^{*}$ \\
\hline Scottish & 0.040 & $0.007^{*}$ & $0.019 *$ & 0.038 & 0.040 \\
\hline \multicolumn{6}{|l|}{ Retailer } \\
\hline Coop & 0.174 & $0.011^{*}$ & $0.026^{*}$ & $0.056^{*}$ & $0.051^{*}$ \\
\hline Lidl & -0.390 & $0.015^{*}$ & $0.034^{*}$ & $0.065^{*}$ & $0.078 *$ \\
\hline Marks & 0.420 & $0.009 *$ & $0.010^{*}$ & $0.052 *$ & $0.057^{*}$ \\
\hline Morissons & -0.006 & 0.011 & 0.018 & 0.050 & 0.053 \\
\hline Sainsbury's & 0.120 & $0.013^{*}$ & $0.010 *$ & $0.067 * *$ & $0.032 *$ \\
\hline Tesco & 0.267 & $0.014 *$ & $0.018^{*}$ & $0.074^{*}$ & $0.066^{*}$ \\
\hline Waitrose & 0.440 & $0.009 *$ & $0.023^{*}$ & $0.049 *$ & $0.053^{*}$ \\
\hline Constant & 2.740 & $0.008^{*}$ & $0.030 *$ & $0.046^{*}$ & $0.035^{*}$ \\
\hline
\end{tabular}

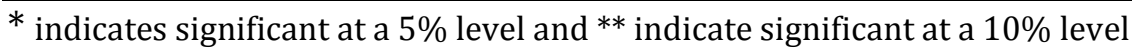


Table 4. Parameter estimates from model 2

\begin{tabular}{|c|c|c|c|c|c|}
\hline \multirow[t]{2}{*}{ Variable } & \multirow[t]{2}{*}{ Parameter } & \multicolumn{3}{|c|}{ St. Error } & \multirow[b]{2}{*}{ Multi } \\
\hline & & No cluster & Retailer & Product & \\
\hline \multicolumn{6}{|l|}{ Species } \\
\hline Chum or Pink & -0.179 & $0.020^{*}$ & $0.075^{*}$ & $0.083^{*}$ & $0.075^{*}$ \\
\hline Sockeye & 0.006 & 0.013 & 0.038 & 0.061 & 0.061 \\
\hline Wild Alaska & -0.047 & 0.061 & 0.196 & 0.205 & 0.166 \\
\hline \multicolumn{6}{|l|}{ Product Form } \\
\hline Fresh & -0.239 & $0.013^{*}$ & $0.090^{*}$ & $0.059 *$ & $0.067^{*}$ \\
\hline Frozen & -0.191 & $0.016^{*}$ & $0.071 *$ & $0.059 *$ & $0.055^{*}$ \\
\hline Flakes & 0.124 & $0.012^{*}$ & $0.058 * *$ & $0.065^{* *}$ & $0.066^{* *}$ \\
\hline Slices & 0.228 & $0.010^{*}$ & $0.067^{*}$ & $0.051^{*}$ & $0.050 *$ \\
\hline Trims & -0.741 & $0.021^{*}$ & $0.122^{*}$ & $0.125^{*}$ & $0.131 *$ \\
\hline Other prod. & -0.197 & $0.034^{*}$ & 0.125 & 0.123 & 0.122 \\
\hline \multicolumn{6}{|l|}{ Processing } \\
\hline Smoked & 0.225 & $0.007^{*}$ & $0.030^{*}$ & $0.040 *$ & $0.031^{*}$ \\
\hline Gravlox & 0.054 & $0.019 *$ & 0.063 & 0.076 & 0.061 \\
\hline Value added & 0.039 & $0.008^{*}$ & 0.050 & 0.037 & 0.044 \\
\hline \multicolumn{6}{|l|}{ Package size } \\
\hline Wgt_90 & 0.521 & $0.025^{*}$ & $0.064^{*}$ & $0.092^{*}$ & $0.104 *$ \\
\hline Wgt_250_500 & -0.298 & $0.007^{*}$ & $0.020^{*}$ & $0.035^{*}$ & $0.032 *$ \\
\hline Wgt_500 & -0.394 & $0.013^{*}$ & $0.029 *$ & $0.054^{*}$ & $0.048 *$ \\
\hline Wgt_ind & -0.334 & $0.014 *$ & $0.052 *$ & $0.056 *$ & $0.044 *$ \\
\hline \multicolumn{6}{|l|}{ Brand } \\
\hline Bird's Eye & 0.326 & $0.023^{*}$ & $0.091^{*}$ & $0.096 *$ & $0.083^{*}$ \\
\hline Young's & 0.098 & $0.016^{*}$ & $0.041^{*}$ & 0.079 & 0.068 \\
\hline Other brand & 0.155 & $0.013^{*}$ & $0.072 *$ & $0.069 *$ & $0.068^{*}$ \\
\hline \multicolumn{6}{|l|}{ Retailer } \\
\hline Coop & 0.142 & $0.015^{*}$ & $0.040^{*}$ & $0.078 * *$ & 0.093 \\
\hline Lidl & -0.429 & $0.018^{*}$ & $0.026^{*}$ & $0.088^{*}$ & $0.095^{*}$ \\
\hline Marks & 0.473 & $0.016^{*}$ & $0.035^{*}$ & $0.094 *$ & $0.119 *$ \\
\hline Morissons & 0.053 & $0.015^{*}$ & $0.020^{*}$ & 0.070 & 0.077 \\
\hline Sainsbury's & 0.128 & $0.031^{*}$ & $0.021^{*}$ & 0.148 & 0.144 \\
\hline Tesco & 0.278 & $0.016^{*}$ & $0.020^{*}$ & $0.085^{*}$ & $0.088^{*}$ \\
\hline Waitrose & 0.466 & $0.012^{*}$ & $0.018^{*}$ & $0.065^{*}$ & $0.073^{*}$ \\
\hline \multicolumn{6}{|l|}{ Retailer*Eco-label } \\
\hline MSC Asda & 0.570 & $0.022^{*}$ & $0.060^{*}$ & $0.087^{*}$ & $0.086^{*}$ \\
\hline MSC Lidl & 0.276 & $0.029 *$ & $0.074^{*}$ & $0.124^{*}$ & $0.118^{*}$ \\
\hline MSC Marks & -0.022 & 0.040 & 0.076 & 0.158 & 0.137 \\
\hline MSC Mor. & 0.224 & $0.063^{*}$ & 0.226 & 0.214 & 0.180 \\
\hline MSC Tes & -0.051 & 0.086 & 0.259 & 0.241 & 0.229 \\
\hline MSC Waitr & 0.107 & $0.026^{*}$ & $0.039 *$ & 0.080 & 0.081 \\
\hline Org Asda & 0.279 & $0.017^{*}$ & $0.032 *$ & $0.105^{*}$ & $0.063^{*}$ \\
\hline Org Marks & 0.255 & $0.016^{*}$ & $0.051^{*}$ & $0.086^{*}$ & $0.106^{*}$ \\
\hline Org Waitr & 0.218 & $0.009 *$ & $0.025^{*}$ & $0.046^{*}$ & $0.038^{*}$ \\
\hline
\end{tabular}




\begin{tabular}{llllll} 
Scot. Asda & 0.058 & $0.014^{*}$ & $0.019^{*}$ & 0.084 & 0.117 \\
Scot. Coop & 0.124 & $0.018^{*}$ & 0.045 & 0.091 & 0.087 \\
Scot Marks & -0.007 & 0.015 & 0.034 & 0.083 & 0.075 \\
Scot Mors & -0.053 & $0.018^{*}$ & 0.030 & 0.078 & 0.078 \\
Scot. Sain & 0.058 & $0.032^{* *}$ & $0.021^{*}$ & 0.150 & 0.226 \\
Scot. Tesco & 0.440 & $0.019^{*}$ & $0.063^{*}$ & $0.100^{*}$ & $0.102^{*}$ \\
Scot. Waitr & 0.044 & $0.013^{*}$ & 0.027 & 0.067 & 0.053 \\
& & & & & \\
Constant & 2.715 & $0.011^{*}$ & $0.027^{*}$ & $0.061^{*}$ & $0.065^{*}$ \\
\hline
\end{tabular}

* indicates significant at a $5 \%$ level and ${ }^{* *}$ indicate significant at a $10 \%$ level 
Table 5. F-tests for model reduction for Model 2

\begin{tabular}{crlrl}
\hline $\mathrm{H}_{0}$ & \multicolumn{2}{c}{ No premium } & \multicolumn{2}{c}{ Equal premium } \\
& $F$-value & $p$-value & $F$-value & $p$-value \\
\hline$f_{k * M S C}$ & 12.97 & 0.000 & 9.73 & 0.000 \\
$f_{k * \text { Organic }}$ & 12.04 & 0.000 & 0.19 & 0.827 \\
$f_{k * \text { Scottish }}$ & 3.57 & 0.001 & 3.60 & 0.002 \\
$f_{k * M S C, \text { Organic,Scottish }}$ & 16.83 & 0.000 & & \\
\hline
\end{tabular}




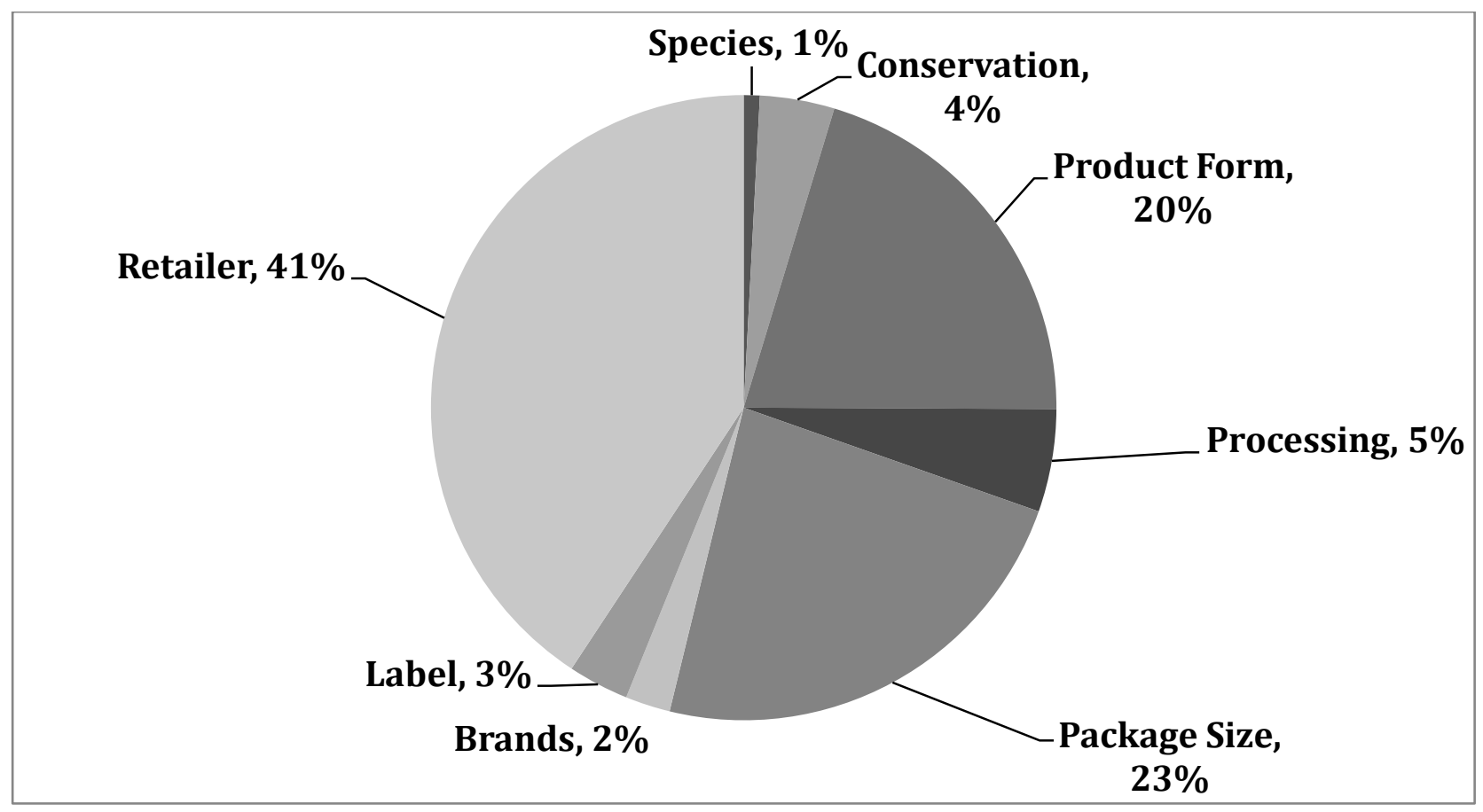

Figure 1. Price variation attributable to variable groups. Based on summing $\eta^{2}$ (partial effects) of covariates within each group. 


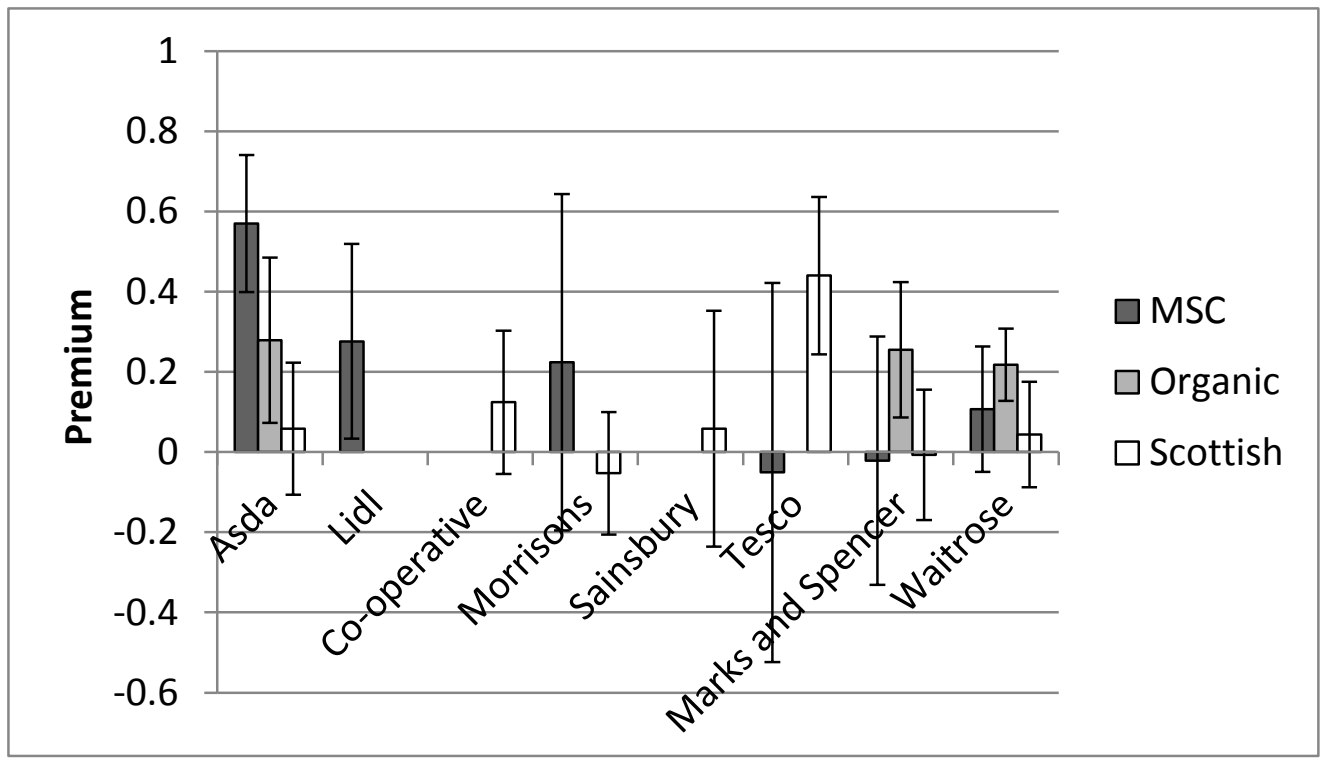

Figure 2. Eco-label and country-of-origin premiums for different retailers. Note: error bars are 95\% confidence interval based on standard errors clustered at the product type level. 


\section{Appendix A}

Table A1. Number of unique products

\begin{tabular}{|c|c|c|c|c|c|c|c|c|}
\hline Outlet & ASDA* & COOP & LIDL & $\begin{array}{c}\text { MARK } \\
\mathbf{S}\end{array}$ & MORS & SAIN & TESC & WAIT \\
\hline Total products & 41 & 22 & 9 & 47 & 32 & 20 & 16 & 36 \\
\hline \multicolumn{9}{|l|}{ Species } \\
\hline Chum/Pink & 6 & 2 & 3 & 1 & 1 & & 1 & 1 \\
\hline Sockeye & 1 & 1 & & & & & & 2 \\
\hline Other wild & 1 & & & 3 & 1 & & 1 & \\
\hline Farmed* & 33 & 19 & 6 & 43 & 30 & 20 & 14 & 33 \\
\hline \multicolumn{9}{|l|}{ Preserved } \\
\hline Chilled* & 28 & 20 & 5 & 46 & 29 & 20 & 14 & 25 \\
\hline Fresh & 5 & & & & 2 & & & 7 \\
\hline Frozen & 8 & 2 & 4 & 1 & 1 & & 2 & 4 \\
\hline \multicolumn{9}{|l|}{ Product form } \\
\hline Fillet* & 35 & 15 & 5 & 29 & 16 & 10 & 13 & 25 \\
\hline Flakes & & & & 2 & 1 & 1 & & 1 \\
\hline Slices & 5 & 5 & 3 & 14 & 11 & 8 & 2 & 7 \\
\hline Trimmings & 1 & 2 & & & 2 & & & 1 \\
\hline Other & & & 1 & 2 & 2 & 1 & 1 & 2 \\
\hline \multicolumn{9}{|l|}{ Processed } \\
\hline Smoked & 19 & 11 & 4 & 26 & 17 & 13 & 5 & 17 \\
\hline Graved & & & 1 & 1 & 1 & & & 1 \\
\hline Added ing. & 4 & 1 & 3 & 8 & 4 & 2 & 4 & 3 \\
\hline \multicolumn{9}{|l|}{ Prod. Wt gr. } \\
\hline$<100$ & & & & 3 & 1 & 1 & & \\
\hline $100-250^{*}$ & 29 & 17 & 7 & 28 & 17 & 14 & 6 & 21 \\
\hline $250-500$ & 5 & 5 & 1 & 10 & 6 & 1 & 6 & 9 \\
\hline$>500$ & 3 & & 1 & 6 & & 2 & 2 & 3 \\
\hline Individual & 4 & & & & 8 & 2 & 2 & 3 \\
\hline \multicolumn{9}{|l|}{ Brand } \\
\hline BEY & 1 & 1 & & & & & 1 & 1 \\
\hline YNG & 2 & 2 & & & 1 & & & \\
\hline Other brands & 1 & 7 & 8 & & 8 & 6 & 3 & 4 \\
\hline Private* & 37 & 12 & 1 & 47 & 29 & 14 & 12 & 31 \\
\hline \multicolumn{9}{|l|}{ Eco-labels } \\
\hline MSC & 3 & & 3 & 2 & 1 & & 1 & 2 \\
\hline Organic & 3 & & & 2 & & & 1 & 4 \\
\hline Unlabeled* & 35 & 22 & 6 & 43 & 31 & 20 & 14 & 30 \\
\hline \multicolumn{9}{|l|}{ Other labels } \\
\hline Scottish & 14 & 11 & 2 & 27 & 16 & 13 & 1 & 14 \\
\hline Price per kg & 16.7 & 21.2 & 11.4 & 29.9 & 17.6 & 23.7 & 19.1 & 26.9 \\
\hline
\end{tabular}

* Base categories in regression 
Table A2. Standard errors with additional clusters for Model 1

\begin{tabular}{|c|c|c|c|c|}
\hline \multirow[t]{2}{*}{ Variable } & \multirow[t]{2}{*}{ Parameter } & \multicolumn{3}{|c|}{ St. Error } \\
\hline & & Species & Preserved & Product form \\
\hline \multicolumn{5}{|l|}{ Species } \\
\hline Chum or Pink & -0.195 & $0.059 *$ & $0.023^{*}$ & $0.057 *$ \\
\hline Sockeye & 0.126 & $0.058^{*}$ & 0.105 & $0.061 *$ \\
\hline Wild Alaska & -0.089 & $0.049^{* *}$ & 0.191 & 0.150 \\
\hline \multicolumn{5}{|l|}{ Preserved } \\
\hline Fresh & -0.255 & $0.027 *$ & $0.047 *$ & $0.047^{*}$ \\
\hline Frozen & -0.187 & $0.070^{*}$ & $0.040 *$ & $0.023^{*}$ \\
\hline \multicolumn{5}{|l|}{ Product Form } \\
\hline Flakes & 0.138 & $0.023 *$ & $0.014 *$ & $0.009 *$ \\
\hline Slices & 0.252 & $0.007 *$ & $0.004 *$ & $0.005^{*}$ \\
\hline Trims & -0.724 & $0.004^{*}$ & $0.008 *$ & $0.032 *$ \\
\hline Other prod. & -0.183 & $0.050^{*}$ & 0.196 & 0.196 \\
\hline \multicolumn{5}{|l|}{ Processing } \\
\hline Smoked & 0.209 & $0.020^{*}$ & $0.013 *$ & $0.049 *$ \\
\hline Gravlox & 0.023 & 0.014 & 0.021 & 0.025 \\
\hline Value added & 0.033 & 0.022 & $0.014 *$ & 0.025 \\
\hline \multicolumn{5}{|l|}{ Package Size } \\
\hline Wgt_90 & 0.516 & $0.178^{*}$ & $0.055^{*}$ & $0.007 *$ \\
\hline Wgt_250_500 & -0.291 & $0.025^{*}$ & $0.017 *$ & $0.042 *$ \\
\hline Wgt_500 & -0.407 & $0.044^{*}$ & $0.022 *$ & $0.045^{*}$ \\
\hline Wgt_ind & -0.339 & $0.046^{*}$ & $0.008 *$ & $0.045^{*}$ \\
\hline \multicolumn{5}{|l|}{ Brand } \\
\hline Bird's Eye & 0.308 & $0.038^{*}$ & $0.017 *$ & $0.030^{*}$ \\
\hline Young's & 0.018 & 0.090 & 0.047 & 0.015 \\
\hline Other brand & 0.126 & $0.002 *$ & $0.001 *$ & $0.044^{*}$ \\
\hline \multicolumn{5}{|l|}{ Eco-label } \\
\hline MSC & 0.131 & $0.054 *$ & $0.040^{*}$ & $0.031 *$ \\
\hline Organic & 0.253 & $0.024 *$ & $0.026^{*}$ & $0.035^{*}$ \\
\hline Scottish & 0.040 & $0.008^{*}$ & 0.040 & 0.071 \\
\hline \multicolumn{5}{|l|}{ Retailer } \\
\hline Coop & 0.174 & $0.048^{*}$ & $0.057^{*}$ & $0.029 *$ \\
\hline Lidl & -0.390 & $0.094 *$ & $0.097 *$ & $0.064 *$ \\
\hline Marks & 0.420 & $0.014^{*}$ & $0.030 *$ & $0.055^{*}$ \\
\hline Morrisons & -0.006 & 0.019 & 0.016 & 0.037 \\
\hline Sainsbury's & 0.120 & $0.016^{*}$ & $0.022 *$ & $0.031^{*}$ \\
\hline Tesco & 0.267 & $0.022 *$ & $0.017 *$ & $0.028^{*}$ \\
\hline Waitrose & 0.440 & $0.022 *$ & $0.041^{*}$ & $0.030^{*}$ \\
\hline Constant & 2.740 & $0.035^{*}$ & $0.037 *$ & $0.021 *$ \\
\hline
\end{tabular}


Table A3. Standard errors with additional clusters for Model 5

\begin{tabular}{|c|c|c|c|c|}
\hline \multirow[t]{2}{*}{ Variable } & \multirow[t]{2}{*}{ Parameter } & \multicolumn{3}{|c|}{ St. Error } \\
\hline & & Species & Preserved & Prod. form \\
\hline \multicolumn{5}{|l|}{ Species } \\
\hline Chum Pink & -0.179 & $0.044 *$ & $0.071 *$ & $0.064 *$ \\
\hline Sockeye & 0.006 & 0.052 & 0.063 & 0.025 \\
\hline Wild Alaska & -0.047 & 0.109 & 0.283 & 0.078 \\
\hline \multicolumn{5}{|l|}{ Preserved } \\
\hline Fresh & -0.239 & $0.010 *$ & $0.045 *$ & $0.039 *$ \\
\hline Frozen & -0.191 & $0.046 *$ & $0.010 *$ & $0.017 *$ \\
\hline \multicolumn{5}{|l|}{ Prouct form } \\
\hline Flakes & 0.124 & $0.017 *$ & $0.012 *$ & $0.028 *$ \\
\hline Slices & 0.228 & $0.010 *$ & $0.010 *$ & $0.017 *$ \\
\hline Trims & -0.741 & $0.007 *$ & $0.009 *$ & $0.039 *$ \\
\hline Other prod. & -0.197 & $0.041 *$ & $0.182 *$ & $0.186 *$ \\
\hline \multicolumn{5}{|l|}{ Processing } \\
\hline Smoked & 0.225 & $0.010 *$ & $0.015 *$ & $0.036 *$ \\
\hline Gravlox & 0.054 & $0.018 *$ & $0.012 *$ & 0.040 \\
\hline Value added & 0.039 & $0.013 *$ & $0.015 *$ & 0.050 \\
\hline \multicolumn{5}{|l|}{ Packet size } \\
\hline Wgt_90 & 0.521 & $0.165^{*}$ & $0.092 *$ & $0.018 *$ \\
\hline Wgt_250_500 & -0.298 & $0.022 *$ & $0.023 *$ & $0.024 *$ \\
\hline Wgt_500 & -0.394 & $0.032 *$ & $0.024 *$ & $0.041 *$ \\
\hline Wgt_ind & -0.334 & $0.012 *$ & $0.013 *$ & $0.039 *$ \\
\hline \multicolumn{5}{|l|}{ Brand } \\
\hline Bird's Eye & 0.326 & $0.032 *$ & $0.036 *$ & $0.010 *$ \\
\hline Young's & 0.098 & 0.099 & 0.097 & $0.024 *$ \\
\hline Other brand & 0.155 & $0.026 *$ & $0.012 *$ & $0.019 *$ \\
\hline \multicolumn{5}{|l|}{ Retailer } \\
\hline Coop & 0.142 & 0.105 & $0.090 *$ & $0.049 *$ \\
\hline Lidl & -0.429 & $0.028 *$ & $0.054 *$ & $0.027 *$ \\
\hline Marks & 0.473 & $0.033 *$ & $0.046 *$ & $0.179 *$ \\
\hline Morrisons & 0.053 & $0.006 *$ & $0.022 *$ & $0.026^{*}$ \\
\hline Sainsbury's & 0.128 & $0.019 *$ & $0.030 *$ & $0.071 * *$ \\
\hline Tesco & 0.278 & $0.006 *$ & $0.022 *$ & $0.031 *$ \\
\hline Waitrose & 0.466 & $0.022 *$ & $0.046^{*}$ & $0.042 *$ \\
\hline \multicolumn{5}{|l|}{ Retailer*Eco-label } \\
\hline MSC Asda & 0.570 & $0.071 *$ & $0.068 *$ & $0.058 *$ \\
\hline MSC Lidl & 0.276 & $0.047 *$ & $0.062 *$ & $0.058 *$ \\
\hline MSC Marks & -0.022 & 0.094 & 0.164 & 0.189 \\
\hline MSC Mor. & 0.224 & $0.122 * *$ & 0.272 & $0.047 *$ \\
\hline MSC Tes. & -0.051 & 0.185 & 0.274 & 0.063 \\
\hline MSC Waitr. & 0.107 & 0.088 & 0.072 & 0.044 \\
\hline Org Asda & 0.279 & $0.024 *$ & $0.036 *$ & $0.074 *$ \\
\hline Org Marks & 0.255 & $0.017 *$ & $0.035^{*}$ & $0.116 *$ \\
\hline Org Waitr. & 0.218 & $0.029 *$ & $0.022 *$ & $0.029 *$ \\
\hline Scot. Asda & 0.058 & $0.021 *$ & 0.038 & 0.153 \\
\hline Scot. Coop & 0.124 & 0.089 & 0.085 & 0.081 \\
\hline Scot Marks & -0.007 & 0.025 & 0.032 & 0.078 \\
\hline Scot Mors. & -0.053 & $0.022 *$ & 0.079 & 0.096 \\
\hline Scot. Sain. & 0.058 & $0.003 *$ & $0.014 *$ & 0.247 \\
\hline Scot. Tesco & 0.440 & $0.024 *$ & $0.025^{*}$ & $0.087^{*}$ \\
\hline Scot. Waitr. & 0.044 & 0.034 & 0.051 & 0.070 \\
\hline Constant & 2.715 & $0.030 *$ & $0.036 *$ & $0.061 *$ \\
\hline
\end{tabular}

* indicates significant at a $5 \%$ level and ** indicate significant at a $10 \%$ level 
Table A4. Parameter estimates from model 2, interactions with MSC

\begin{tabular}{|c|c|c|c|c|c|}
\hline \multirow[t]{2}{*}{ Variable } & \multirow[t]{2}{*}{ Parameter } & \multicolumn{4}{|c|}{ St. Error } \\
\hline & & No cluster & Retailer & Product & Multi \\
\hline \multicolumn{6}{|l|}{ Species } \\
\hline Chum pink & -0.181 & $0.019^{*}$ & $0.077 *$ & $0.083 *$ & $0.072 *$ \\
\hline Sockeye & -0.021 & 0.012 & 0.052 & 0.059 & 0.064 \\
\hline Wild Alaska & -0.020 & 0.062 & 0.188 & 0.213 & 0.164 \\
\hline \multicolumn{6}{|l|}{ Conservtion } \\
\hline Fresh & -0.240 & $0.013^{*}$ & $0.088^{*}$ & $0.060^{*}$ & $0.070 *$ \\
\hline Frozen & -0.191 & $0.016^{*}$ & $0.072 *$ & $0.061 *$ & $0.056^{*}$ \\
\hline \multicolumn{6}{|l|}{ Product form } \\
\hline Flakes & 0.127 & $0.011 *$ & $0.054 *$ & $0.060 *$ & $0.059 *$ \\
\hline Slices & 0.246 & $0.009 *$ & $0.059 *$ & $0.050 *$ & $0.043 *$ \\
\hline Trims & -0.727 & $0.021 *$ & $0.116^{*}$ & $0.124 *$ & $0.129 *$ \\
\hline Other prod. & -0.192 & $0.034 *$ & 0.124 & 0.126 & 0.124 \\
\hline \multicolumn{6}{|l|}{ Processing } \\
\hline Smoked & 0.206 & $0.007 *$ & $0.024 *$ & $0.038^{*}$ & $0.032 *$ \\
\hline Gravlox & 0.037 & $0.018^{*}$ & 0.061 & 0.070 & 0.062 \\
\hline Value added & 0.026 & $0.008 *$ & 0.047 & 0.037 & 0.040 \\
\hline \multicolumn{6}{|l|}{ Packet size } \\
\hline Wgt_90 & 0.487 & $0.025^{*}$ & $0.069 *$ & $0.095^{*}$ & $0.102 *$ \\
\hline Wgt_250_500 & -0.303 & $0.007 *$ & $0.019 *$ & $0.035^{*}$ & $0.032 *$ \\
\hline Wgt_500 & -0.418 & $0.013^{*}$ & $0.028 *$ & $0.051 *$ & $0.047 *$ \\
\hline Wgt_ind & -0.366 & $0.013^{*}$ & $0.056^{*}$ & $0.052 *$ & $0.042 *$ \\
\hline \multicolumn{6}{|l|}{ Brand } \\
\hline Bird's Eye & 0.299 & $0.021 *$ & $0.094 *$ & $0.090 *$ & $0.083 *$ \\
\hline Young's & 0.066 & $0.016^{*}$ & 0.054 & 0.085 & 0.078 \\
\hline Other brand & 0.120 & $0.012 *$ & $0.067 * *$ & $0.061^{* *}$ & $0.062 * *$ \\
\hline \multicolumn{6}{|l|}{ Eco-label } \\
\hline Organic & 0.247 & $0.008^{*}$ & $0.026^{*}$ & $0.047 *$ & $0.035^{*}$ \\
\hline Scottish & 0.042 & $0.007 *$ & $0.020 *$ & 0.038 & 0.041 \\
\hline \multicolumn{6}{|l|}{ Retailer } \\
\hline Coop & 0.180 & $0.010^{*}$ & $0.026^{*}$ & $0.055^{*}$ & $0.052 *$ \\
\hline Lidl & -0.447 & $0.015^{*}$ & $0.023 *$ & $0.071^{*}$ & $0.073^{*}$ \\
\hline Marks & 0.435 & $0.010^{*}$ & $0.012 *$ & $0.054 *$ & $0.061^{*}$ \\
\hline Morrisons & 0.005 & 0.011 & 0.017 & 0.050 & 0.050 \\
\hline Sainsbury’s & 0.131 & $0.013^{*}$ & $0.008^{*}$ & $0.067 *$ & $0.029 *$ \\
\hline Tesco & 0.290 & $0.014 *$ & $0.017 *$ & $0.075^{*}$ & $0.039^{*}$ \\
\hline Waitrose & 0.454 & $0.009 *$ & $0.016^{*}$ & $0.049 *$ & $0.052 *$ \\
\hline \multicolumn{6}{|l|}{ Retailer*MSC } \\
\hline MSC Asda & 0.605 & $0.020 *$ & $0.066^{*}$ & $0.078^{*}$ & $0.070^{*}$ \\
\hline MSC Lidl & 0.308 & $0.028 *$ & $0.070^{*}$ & $0.117^{*}$ & $0.105^{*}$ \\
\hline MSC Marks & -0.020 & 0.039 & 0.093 & 0.149 & 0.119 \\
\hline MSC Mor. & 0.222 & $0.064 *$ & 0.216 & 0.217 & 0.166 \\
\hline MSC Tes & -0.089 & 0.087 & 0.255 & 0.245 & 0.218 \\
\hline MSC Waitr. & 0.139 & $0.026^{*}$ & $0.057 *$ & $0.076^{* *}$ & $0.077 * *$ \\
\hline Constant & 2.740 & $0.008 *$ & $0.027 *$ & $0.046^{*}$ & $0.037 *$ \\
\hline
\end{tabular}

* indicates significant at a 5\% level and $* *$ indicate significant at a $10 \%$ level 
Table A5. Parameter estimates from model 3, interactions with organic

\begin{tabular}{|c|c|c|c|c|c|}
\hline \multirow[t]{2}{*}{ Variable } & \multirow[t]{2}{*}{ Parameter } & \multicolumn{3}{|c|}{ St. Error } & \multirow[b]{2}{*}{ Multi } \\
\hline & & No cluster & Retailer & Product & \\
\hline \multicolumn{6}{|l|}{ Species } \\
\hline Chum pink & -0.191 & $0.020^{*}$ & $0.089^{*}$ & $0.095^{*}$ & $0.088^{*}$ \\
\hline Sockeye & 0.120 & $0.029 *$ & 0.097 & 0.132 & 0.123 \\
\hline Wild Alaska & -0.087 & $0.043 *$ & 0.142 & 0.163 & 0.136 \\
\hline \multicolumn{6}{|l|}{ Preserved } \\
\hline Fresh & -0.259 & $0.013^{*}$ & $0.081^{*}$ & $0.061 *$ & $0.066^{*}$ \\
\hline Frozen & -0.188 & $0.014^{*}$ & $0.081^{*}$ & $0.057 *$ & $0.056^{*}$ \\
\hline \multicolumn{6}{|l|}{ Product form } \\
\hline Flakes & 0.138 & $0.011^{*}$ & $0.056^{*}$ & $0.060^{*}$ & $0.057^{*}$ \\
\hline Slices & 0.252 & $0.009 *$ & $0.059 *$ & $0.050^{*}$ & $0.044^{*}$ \\
\hline Trims & -0.724 & $0.021^{*}$ & $0.117 *$ & $0.125^{*}$ & $0.130 *$ \\
\hline Other prod. & -0.191 & $0.035^{*}$ & 0.128 & 0.128 & 0.126 \\
\hline \multicolumn{6}{|l|}{ Processing } \\
\hline Smoked & 0.209 & $0.007 *$ & $0.024 *$ & $0.038^{*}$ & $0.032 *$ \\
\hline Gravlox & 0.022 & 0.020 & 0.066 & 0.080 & 0.068 \\
\hline Value added & 0.031 & $0.008^{*}$ & 0.045 & 0.037 & 0.041 \\
\hline \multicolumn{6}{|l|}{ Packet size } \\
\hline Wgt_90 & 0.517 & $0.022 *$ & $0.075^{*}$ & $0.104 *$ & $0.113^{*}$ \\
\hline Wgt_250_500 & -0.294 & $0.007 *$ & $0.023^{*}$ & $0.036^{*}$ & $0.030 *$ \\
\hline Wgt_500 & -0.408 & $0.012 *$ & $0.026^{*}$ & $0.048^{*}$ & $0.042 *$ \\
\hline Wgt_ind & -0.326 & $0.014^{*}$ & $0.044^{*}$ & $0.057 *$ & $0.047 *$ \\
\hline \multicolumn{6}{|l|}{ Brand } \\
\hline Bird's Eye & 0.303 & $0.023^{*}$ & $0.115^{*}$ & $0.098 *$ & $0.087^{*}$ \\
\hline Young's & 0.020 & 0.017 & 0.039 & 0.092 & 0.080 \\
\hline Other brand & 0.127 & $0.011^{*}$ & $0.069^{* *}$ & $0.059^{*}$ & $0.061^{*}$ \\
\hline \multicolumn{6}{|l|}{ Eco-label } \\
\hline MSC & 0.128 & $0.025^{*}$ & 0.102 & 0.107 & 0.090 \\
\hline Scottish & 0.040 & $0.007 *$ & $0.019^{*}$ & 0.038 & 0.041 \\
\hline Coop & 0.176 & $0.011^{*}$ & $0.025^{*}$ & $0.056^{*}$ & $0.050^{*}$ \\
\hline \multicolumn{6}{|l|}{ Retailer } \\
\hline Lidl & -0.387 & $0.015^{*}$ & $0.034 *$ & $0.066^{*}$ & $0.078 *$ \\
\hline Marks & 0.420 & $0.010^{*}$ & $0.009^{*}$ & $0.054^{*}$ & $0.060 *$ \\
\hline Morrisons & -0.008 & 0.011 & 0.017 & 0.051 & 0.051 \\
\hline Sainsbury’s & 0.121 & $0.013^{*}$ & $0.011^{*}$ & $0.068^{*}$ & $0.032 *$ \\
\hline Tesco & 0.280 & $0.015^{*}$ & $0.019^{*}$ & $0.076^{*}$ & $0.043^{*}$ \\
\hline Waitrose & 0.445 & $0.010^{*}$ & $0.024^{*}$ & $0.053^{*}$ & $0.057^{*}$ \\
\hline \multicolumn{6}{|l|}{ Retailer*Organic } \\
\hline Org. Asda & 0.268 & $0.017 *$ & $0.029 *$ & $0.104^{*}$ & $0.038^{*}$ \\
\hline Org. Marks & 0.287 & $0.011 *$ & $0.032 *$ & $0.058^{*}$ & $0.065^{*}$ \\
\hline Org. Wait. & 0.233 & $0.008^{*}$ & $0.025^{*}$ & $0.044 *$ & $0.044^{*}$ \\
\hline Constant & 2.739 & $0.009^{*}$ & $0.029 *$ & $0.048^{*}$ & $0.037 *$ \\
\hline
\end{tabular}

* indicates significant at a 5\% level and $* *$ indicate significant at a $10 \%$ level 
Table A6. Parameter estimates from model 4, interaction variables with Scottish origin

\begin{tabular}{|c|c|c|c|c|c|}
\hline \multirow[t]{2}{*}{ Variable } & \multirow[t]{2}{*}{ Parameter } & \multicolumn{3}{|c|}{ St. Error } & \multirow[b]{2}{*}{ Multi } \\
\hline & & No cluster & Retailer & Product & \\
\hline \multicolumn{6}{|l|}{ Species } \\
\hline Chumpink & -0.200 & $0.020^{*}$ & $0.085^{*}$ & $0.093^{*}$ & $0.084 *$ \\
\hline Sockeye & 0.147 & $0.029^{*}$ & 0.097 & 0.131 & 0.121 \\
\hline Wild Alaska & -0.099 & $0.043^{*}$ & 0.147 & 0.159 & 0.136 \\
\hline \multicolumn{6}{|l|}{ Conservation } \\
\hline Fresh & -0.253 & $0.013^{*}$ & $0.081 *$ & $0.059^{*}$ & $0.065^{*}$ \\
\hline Frozen & -0.184 & $0.014^{*}$ & $0.076^{*}$ & $0.054^{*}$ & $0.053^{*}$ \\
\hline \multicolumn{6}{|l|}{ Product form } \\
\hline Flakes & 0.136 & $0.012 *$ & $0.058 *$ & $0.063 *$ & $0.063^{*}$ \\
\hline Slices & 0.232 & $0.010^{*}$ & $0.068^{*}$ & $0.051^{*}$ & $0.050 *$ \\
\hline Trims & -0.744 & $0.021 *$ & $0.122 *$ & $0.126^{*}$ & $0.132 *$ \\
\hline Other prod. & -0.179 & $0.034^{*}$ & 0.137 & 0.125 & 0.123 \\
\hline \multicolumn{6}{|l|}{ Processing } \\
\hline Smoked & 0.232 & $0.007 *$ & $0.030^{*}$ & $0.039^{*}$ & $0.028 *$ \\
\hline Gravlox & 0.046 & $0.021 *$ & 0.069 & 0.088 & 0.070 \\
\hline Value added & 0.048 & $0.008^{*}$ & 0.046 & 0.037 & 0.045 \\
\hline \multicolumn{6}{|l|}{ Packet size } \\
\hline Wgt_90 & 0.546 & $0.022 *$ & $0.064 *$ & $0.097 *$ & $0.113 *$ \\
\hline Wgt_250_500 & -0.286 & $0.007 *$ & $0.025^{*}$ & $0.036^{*}$ & $0.033 *$ \\
\hline Wgt_500 & -0.385 & $0.012^{*}$ & $0.026^{*}$ & $0.050^{*}$ & $0.044 *$ \\
\hline Wgt_ind & -0.322 & $0.013^{*}$ & $0.053^{*}$ & $0.055^{*}$ & $0.044 *$ \\
\hline \multicolumn{6}{|l|}{ Brand } \\
\hline Bird's Eye & 0.342 & $0.023^{*}$ & $0.106^{*}$ & $0.102^{*}$ & $0.083 *$ \\
\hline Young's & 0.049 & $0.017 *$ & 0.048 & 0.090 & 0.073 \\
\hline Other brand & 0.158 & $0.012^{*}$ & $0.069^{*}$ & $0.066^{*}$ & $0.065^{*}$ \\
\hline \multicolumn{6}{|l|}{ Eco-label } \\
\hline MSC & 0.122 & $0.025^{*}$ & 0.100 & 0.107 & 0.088 \\
\hline Organic & 0.257 & $0.008^{*}$ & $0.025^{*}$ & $0.046^{*}$ & $0.037 *$ \\
\hline \multicolumn{6}{|l|}{ Retailer } \\
\hline Coop & 0.129 & $0.015^{*}$ & $0.039^{*}$ & $0.076^{* *}$ & 0.090 \\
\hline Lidl & -0.389 & $0.016^{*}$ & $0.030^{*}$ & $0.074^{*}$ & $0.087 *$ \\
\hline Marks & 0.443 & $0.014^{*}$ & $0.022^{*}$ & $0.079 *$ & $0.094 *$ \\
\hline Morrisons & 0.043 & $0.014^{*}$ & $0.020^{*}$ & 0.067 & 0.074 \\
\hline Sainsbury's & 0.105 & $0.031^{*}$ & $0.023^{*}$ & 0.147 & 0.144 \\
\hline Tesco & 0.237 & $0.015^{*}$ & $0.021^{*}$ & $0.078^{*}$ & $0.081 *$ \\
\hline Waitrose & 0.428 & $0.011^{*}$ & $0.030^{*}$ & $0.058^{*}$ & $0.065^{*}$ \\
\hline \multicolumn{6}{|l|}{ Retailer ${ }^{*}$ Scottish } \\
\hline Scottish Asda & 0.041 & $0.014^{*}$ & $0.022 *$ & 0.079 & 0.107 \\
\hline Scottish Coop & 0.121 & $0.018^{*}$ & $0.043^{*}$ & 0.090 & 0.084 \\
\hline Scottish Marks & 0.003 & 0.013 & 0.020 & 0.073 & 0.054 \\
\hline Scottish Morr. & -0.066 & $0.018^{*}$ & $0.030^{*}$ & 0.076 & 0.076 \\
\hline Scottish Sain. & 0.064 & $0.032 *$ & $0.020^{*}$ & 0.151 & 0.224 \\
\hline Scottish Tesco & 0.469 & $0.018^{*}$ & $0.061 *$ & $0.096^{*}$ & $0.099 *$ \\
\hline Scottish Wait. & 0.064 & $0.013^{*}$ & $0.036^{*}$ & 0.067 & 0.057 \\
\hline Constant & 2.724 & $0.010 *$ & $0.032 *$ & $0.056^{*}$ & $0.058 *$ \\
\hline
\end{tabular}

* indicates significant at a 5\% level and ** indicate significant at a $10 \%$ level 
Figure A1. Frozen salmon fillets. Packages containing two frozen fillet portions from the retailer Lidl's own brand Trawlic. The top is an unlabeled product, while the bottome carries the MSC label in the lower right corner.

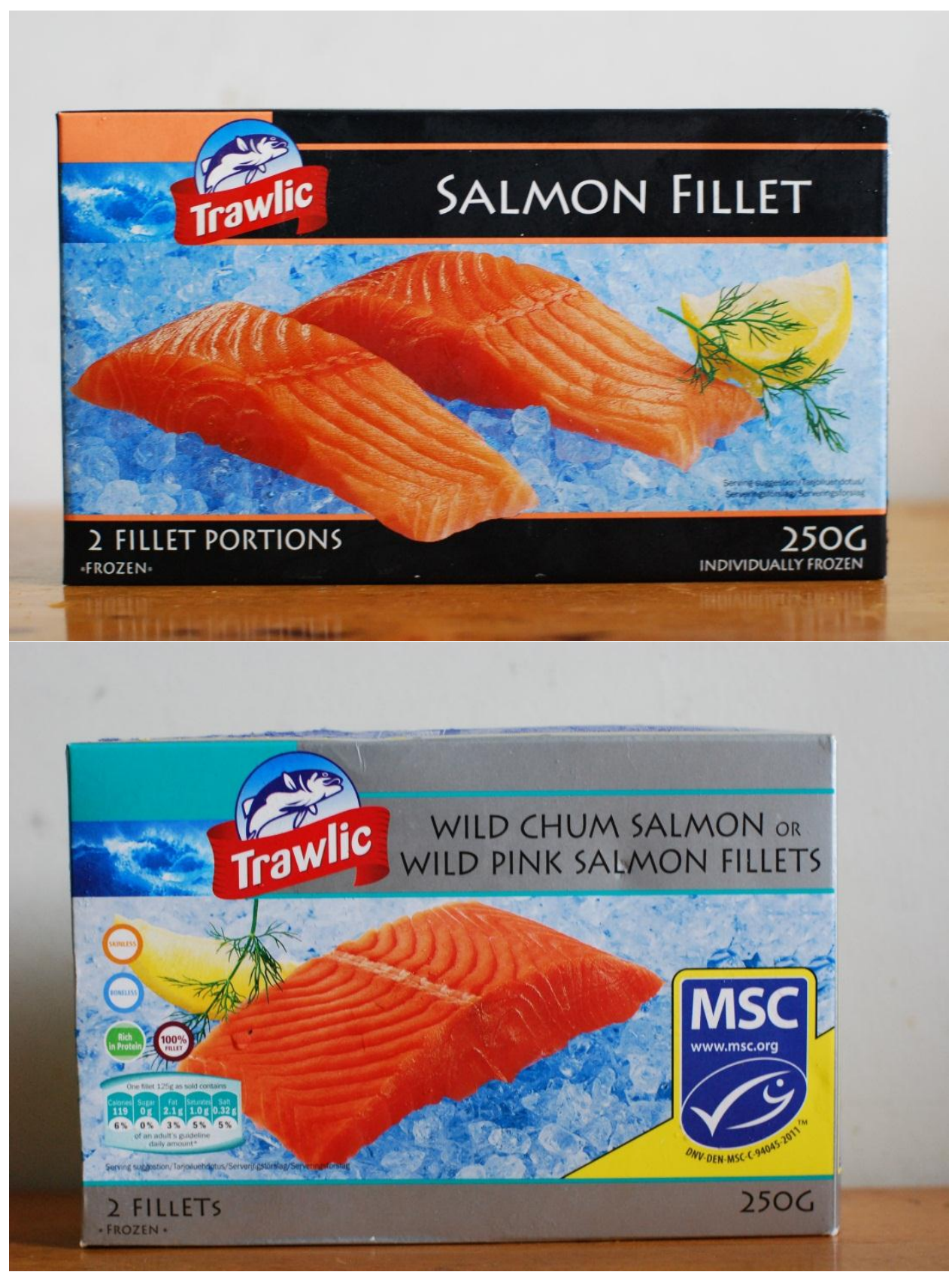


Figure A2. Fresh salmon fillets. The top image is from Morrisons with a Scottish label in the lower right corner of the main section of the product label. The bottom two images are both from ASDA, one unlabeled (middle) and one with an organic label (bottom).
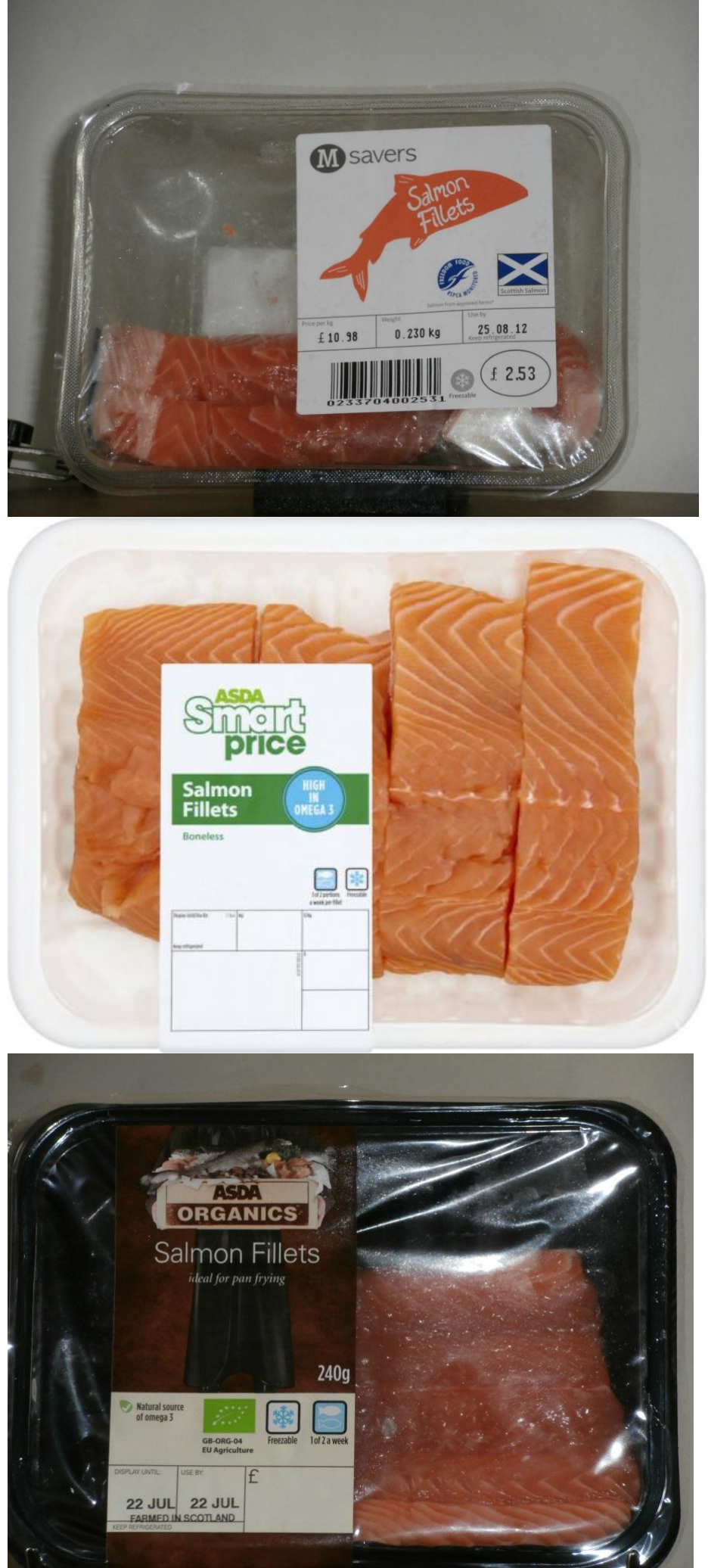